Article

\title{
From XS to XL Urban Nature: Examining Access to Different Types of Green Space Using a 'Just Sustainabilities' Framework
}

\author{
Dong-ah Choi ${ }^{1}\left(\mathbb{D}\right.$, Keunhyun Park ${ }^{2} \mathbb{C}$ and Alessandro Rigolon ${ }^{1, * \mathbb{C}}$ \\ 1 Department of City and Metropolitan Planning, University of Utah, 375 South 1530 East, Suite 220, \\ Salt Lake City, UT 84112, USA; dongah.choi@utah.edu \\ 2 Department of Landscape Architecture and Environmental Planning, Utah State University, \\ 4005 Old Main Hill, Logan, UT 84322, USA; keunhyun.park@usu.edu \\ * Correspondence: alessandro.rigolon@utah.edu; Tel.: +1-801-581-3909
}

Received: 14 July 2020; Accepted: 25 August 2020; Published: 27 August 2020

\begin{abstract}
Different types of urban green spaces provide diverse benefits for human health and environmental sustainability, but most studies on access to green space focus on neighborhood parks, with less work on smaller or larger green spaces. In this study, we examined sociodemographic differences in access to green spaces of different sizes for 14,385 census block groups in 12 U.S. cities using a 'just sustainabilities' framework. We classified green spaces into street-level greenery (XS), neighborhood parks (S-L; walking and cycling access), and large parks (XL; walking, cycling, and driving access). We ran spatial filtering models at the census block group level using different thresholds based on transportation modes. We uncovered a complex picture of inequality, with consistent injustices for XS green space, and fewer injustices for S-L and XL green space based on socioeconomic status and age, and some instances of just distributions for S-L and XL green space based on race/ethnicity. Our findings present a concerning picture for 'just sustainabilities': the green space type that is most often part of sustainability and climate adaptation strategies-street greenery-is unjustly distributed, likely as a result of structural racism in U.S. institutions. By examining multimodal access to green spaces of different sizes, this study helps urban greening professionals develop more just and sustainable strategies.
\end{abstract}

Keywords: green space; street greenery; green space size; environmental justice; just sustainabilities

\section{Introduction}

\subsection{Access to Green Space}

Urban green space is a central element of sustainable cities, providing multiple health, environmental, social and economic benefits [1,2]. A growing body of literature suggests that the type and magnitude of such benefits may vary by the size of green spaces. The smallest type of green spaces (XS), such as street-level greenery, improve thermal comfort and aesthetic value in daily living environments, increase abutting property values, and bolster ecological functions [3-6]. As local destinations, neighborhood parks and trails (S-L) function as community gathering places, increase neighborhood satisfaction, and have particularly significant economic impacts on nearby property values [1,7-11]. As regional or national travel destinations, large parks-including regional parks, state parks, and national forests and parks $(\mathrm{XL})$ - have strong benefits for human health and sustainability, as they provide diverse recreational resources and increased ecological diversity [12-18]. Thus, green spaces of different sizes have unique benefits for environmental sustainability and human health, and they can serve complementary functions to improve urban residents' quality of life $[19,20]$. 
A large body of research shows that neighborhood parks (S-L nature) are unjustly distributed across the cities of the Global North and Global South, with low-income and racial/ethnic minority people having lower access to such parks than more privileged groups [2,21-23]. Although no systematic review has examined environmental justice issues in the access to green spaces of different sizes, our analysis of the literature to date shows that there might be injustices for street-level greenery (XS) and large parks (XL), in addition to neighborhood parks (S-L), for which reviews are available [21]. Regarding XS urban nature, several studies have found that trees (in private and public settings) are unjustly distributed across income and racial/ethnic groups [24-27], fewer have focused on publicly accessible street trees [28,29], and even fewer have examined street greenery [30], also finding evidence of injustice. Not many studies have examined access to XL green spaces (i.e., large parks), but those studies generally found that large parks are unjustly distributed [31-34].

\subsection{Environmental Justice and Just Sustainabilities}

Uneven distributions of green space have been deemed environmental injustices due to the numerous benefits that green spaces provide for human health and environmental sustainability [31,33]. Many scholars have defined environmental justice as a tripartite concept [35]: distributional justice, involving a just distribution of environmental hazards and amenities; procedural justice, describing the meaningful participation of low-income people of color to environmental decision-making; and recognition, involving the inclusion of the different cultures and needs of the demographic groups affected by environmental policies. Based on this definition, the unequal access to green space mentioned above is considered a distributional injustice [31,36]. In the U.S., studies have linked these injustices to the legacy of structural racism, as redlining, racially restrictive covenants, and real estate practices have led to the segregation of low-income people of color in disinvested, park-poor neighborhoods $[31,33]$.

Like others [31,36-38], we argue that definitions of distributional justice should adopt an equity lens to consider the populations who need environmental amenities the most. In this sense, a just distribution of green space is one wherein marginalized groups (e.g., low-income and racial/ethnic minority people) have better access to green space than more privileged people (e.g., affluent and white people), and an unjust distribution is when the opposite occurs. A major needs-based consideration of our equity lens is that low-income people and people of color experience worse physical and mental health outcomes than more privileged groups around the world [39-42], and green space exposure helps improve health $[43,44]$. Another needs-based consideration for the definition of distributional justice is that public green spaces are freely accessible to anyone, including low-income people, whereas some private recreation and exercise opportunities might not be accessible to low-income people due to monetary constraints (e.g., sports clubs, gyms) $[45,46]$. On the flip side, affluent people might have the means to access private recreation settings [47].

Furthermore, race and ethnicity are central to the environmental justice movement, which around the world has sought to reverse the negative environmental impacts of structural racism [48-50]. In the U.S., the movement originated from Black people mobilizing to denounce their excessive exposure to environmental hazards such as landfills [49], whereas, in the Global South, indigenous people have protested the negative environmental and health impacts of colonialism [48,51]. Additionally, environmental injustice can occur at different scales, including between neighborhoods, cities, and even world regions [48,52]. Indeed, significant injustices exist between the Global North and Global South, which suffers disproportionately from harmful exposures and the effects of climate change [48,51].

Increasingly, green space planners and advocates recognize that sustainable initiatives such as new green spaces should also be just [53-55]. Julian Agyeman and colleagues conceptualized this integration of environmental justice values into sustainability initiatives and framework as "just sustainabilities," as a way to fill an "equity deficit" in sustainability efforts [35,53]. Specifically, Agyeman's definition of 'just sustainabilities' includes four conditions [35]: (1) improved well-being and quality of life; (2) ensuring that the needs of current and future generations are met, (3) environmental justice and 
equity, including distributional justice, procedural justice and recognition; and (4) living within the limits of our planet's ecosystems. These conditions integrate key elements from the definitions of sustainability—including the environment, the economy, and equity (see [56])—and environmental justice (see [57]). Importantly, by mentioning an equity deficit, the definition of 'just sustainabilities' implicitly recognizes the usefulness of an equity lens to determine environmental justice outcomes [38], which aligns with the equity-based approach we use in this paper.

Similar to Agyeman, Boone and Fragkias argued that vulnerability science can help integrate sustainability and environmental justice by emphasizing reducing harm on people and the environment [58]. A vulnerability lens that seeks to limit both harms is particularly important because marginalized groups bear a disproportionate burden from the effects of climate change [59]. In the context of urban green spaces, the 'just sustainabilities' framework [35] can serve to highlight the need for green space to be justly distributed, and the need to improve the quality of life for all, now and in the future, with the understanding that more green space can help humans live within the limits of the earth's ecosystems.

\subsection{Study Purpose}

As noted earlier, although several environmental justice studies have focused on access to neighborhood parks ( $S$ to L urban nature), significantly fewer investigations have focused on street greenery and large parks (XS and XL urban nature, respectively). Furthermore, to our knowledge, no empirical study has comparatively examined access to urban green spaces of different sizes (from XS to $\mathrm{XL}$ ) for the same sample of urbanized areas, and no systematic review has assessed this topic either.

Given these literature gaps, the purpose of this study is to analyze sociodemographic differences in access to green spaces of different sizes (from XS to XL) for a diverse sample of urbanized areas in the U.S. using the 'just sustainabilities' framework conceptualized by Agyeman [35]. This 'just sustainabilities' framework is useful to examine accessibility to urban green spaces for at least three reasons. First, green spaces of different sizes bring diverse benefits for environmental systems and quality of life, as they can support different types of activities $[1,3,18]$. Indeed, street greenery may serve as a city's 'everyday green', whereas large parks are more likely to be used for longer contacts with nature (e.g., hiking). Second, distinguishing which sociodemographic groups have higher access to different sizes of green spaces, including whether environmental injustices exist, can help green space planners, park advocates, and elected officials implement targeted policies and programs to achieve justice for green spaces of different sizes. Finally, different organizations plan and manage green spaces of various sizes-from community forestry nonprofits to parks and recreation departments to national park agencies [60,61] - to achieve various sustainability and livability goals and, therefore, the results of our study can inform the work of all such organizations.

This study makes several contributions to both the growing literature on access to green space and sustainability practice. First, the main contribution is an examination of the accessibility of different scales of green spaces, which, as noted earlier, can both advance our understanding of environmental injustices and help green space organizations develop strategies to address them. Second, while studies examined the presence of vegetation and trees in both public and private settings [25], we analyze public green space. Focusing on street greenery as the XS green space measure allows us to describe small-scale green spaces that can be enjoyed by the public (as opposed, for example, to backyards). Third, by examining access to green spaces of different sizes in a relatively large sample of urbanized areas $(n=12)$, we shed light on whether the scale of green space matters in environmental justice outcomes. Finally, we recognize that travel to green spaces of different scales might occur through various travel modes, and include those travel modes in our analysis, whereas much previous literature focused on walking access to green spaces alone (e.g., [21,25]). 


\section{Materials and Methods}

\subsection{Study Areas}

The study areas are 12 U.S. Census Urban Areas systematically selected to represent urban regions of various population sizes and diverse geographical contexts (see Table 1 and Figure 1). The U.S. Census Bureau identifies urban areas as "a densely settled core of census tracts and/or census blocks that meet minimum population density requirements (at least 1000 people per square mile)," which also commonly include abutting territory with lower population density [62]. This definition is useful because the areas of interest in this study are urban neighborhoods that, given limited public resources, de facto compete with each other for green spaces, unlike exurban areas that might be rich in natural environments.

Table 1. Regional context, population size, climate, sociodemographic, and green space information by urban area.

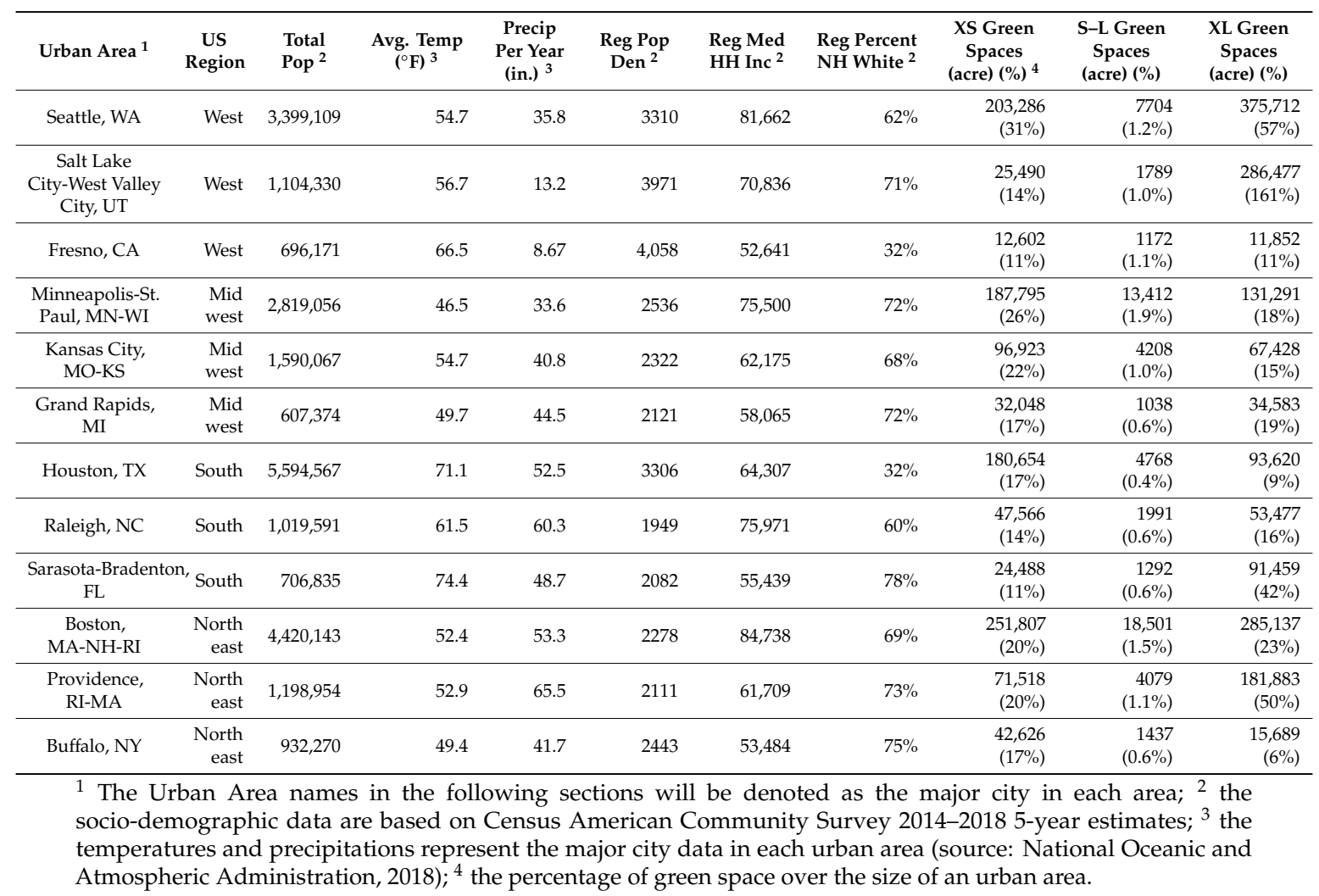

To select study areas, we first classified all of the U.S. Census Urban Areas into 12 categories defined by three different population sizes (more than 2 million, more than 1 million and less than 2 million, and more than 0.5 million and less than 1 million) and four U.S. regions (West, South, Midwest, and Northeast). As urban agglomerations with a continuously built-up area (also called metropolitan areas) commonly consist of at least a population of 0.5 million or higher [63], we used this number as the lowest threshold and created categories enabling a selection urban regions of various sizes. Then, we selected one urban area from each of the 12 categories to obtain a geographically dispersed sample across the country. The 12 urban areas included in the sample also represent various population sizes (from 5.6 million in Houston, TX, to 0.6 million in Grand Rapids, MI), average temperatures (from $7.5^{\circ} \mathrm{C}$ in Minneapolis-St. Paul, MN, to $23.5^{\circ} \mathrm{C}$ in Sarasota-Bradenton, FL), and annual precipitations (from 8.7 inches in Fresno, CA, to 65.5 inches in Providence, RI-MA). These diverse characteristics both enhance the generalizability of our findings and allow for comparisons within the sample. 


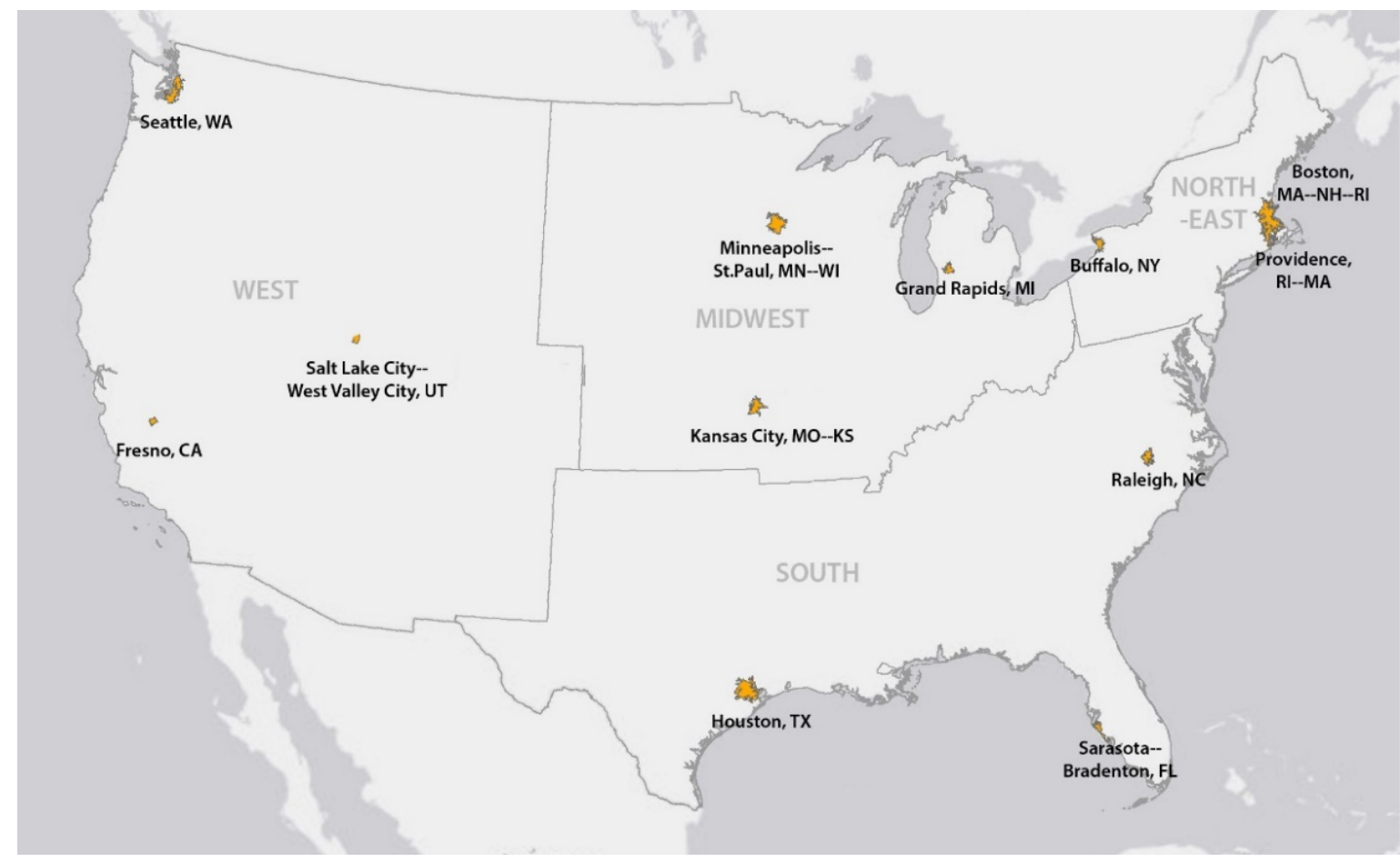

Figure 1. Study areas: 12 urban census areas that represent urban communities of various population sizes and diverse geographical contexts.

\subsection{Green Space Data}

Nature in urban environments exists in various forms and sizes. On the smallest scale, residents might be exposed to street greenery during their daily outdoor activities and on travel routes. On the other side of the size continuum, larger-scale green spaces include large parks, which people visit to enjoy a variety of wildlife and recreational programs, often traveling farther from home to reach these destinations. As green spaces of different sizes support different types of activities [1], we define urban green spaces in three different categories based on their size: extra-small (XS), small to large $(\mathrm{S}-\mathrm{L})$, and extra-large $(\mathrm{XL})$ green spaces.

\subsubsection{XS Green Spaces}

We define XS green spaces as street greenery, which includes vegetation accessed or viewed on the street, including street trees, park strips, front yards, and median strips $[3,30,64]$. Street greenery does not have a consolidated planning and management system, as some elements are managed by private individuals or companies (e.g., front yards), whereas others are controlled by public agencies (e.g., median strips). Regardless, XS nature can help improve physical health outcomes by promoting physical activity, and mental health outcomes by helping relieve stress $[65,66]$.

We collected data to operationalize XS nature from aerial images generated by the U.S. National Agriculture Imagery Program (NAIP) in 2014-2016. NAIP aerial images are remotely-sensed during the agricultural growing seasons, and are available in one-meter resolution or finer; thus, such 'leaf-on' images can efficiently represent vegetation in urban neighborhood streets. NAIP images include four color bands (red, green, blue, and near infrared), which were used to calculate the Normalized Difference Vegetation Index (NDVI). NDVI is a popular indicator to operationalize vegetation [67].

Following the NDVI standards used in earlier studies [68,69], we used an NDVI value of 0.12 or higher to identify any vegetated pixels from the aerial images. After creating vegetation raster images, we removed vegetation that cannot be accessed or viewed on public streets by using buffers around street centerlines to measure street-level greenery (see Figure 2). For the road buffers, we utilized the 
2019 Census TIGER (Topologically Integrated Geographic Encoding and Referencing) Road shapefiles, and created a buffer from street centerlines of 100 feet $(30.48 \mathrm{~m})$ for main arterials, and a buffer of 50 feet $(15.24 \mathrm{~m})$ for local neighborhood roads [70]. The two different buffers take into account the width of the main arteries and neighborhood roads. Based on guidelines from the American Association of State Highway and Transportation Officials [71], we estimated the total width of arterial streets-including more than two travel lanes, shoulders, sidewalks and front yards in each direction—as 200 feet $(60.96 \mathrm{~m})$. Applying similar logic, we estimated the width of local neighborhood streets with two travel lanes and other street elements as $100 \mathrm{ft}$.

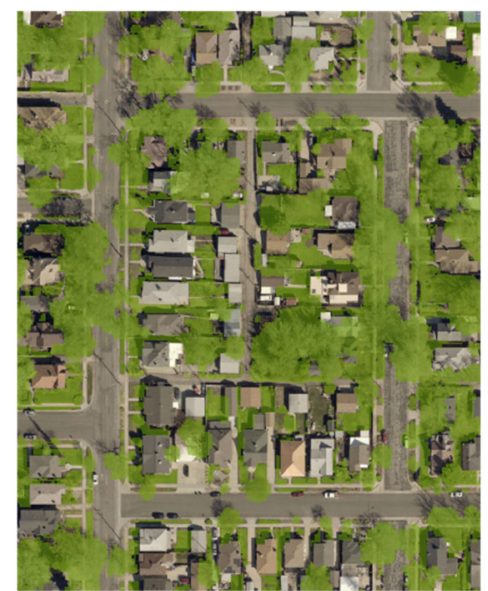

(1) Vegetation raster images

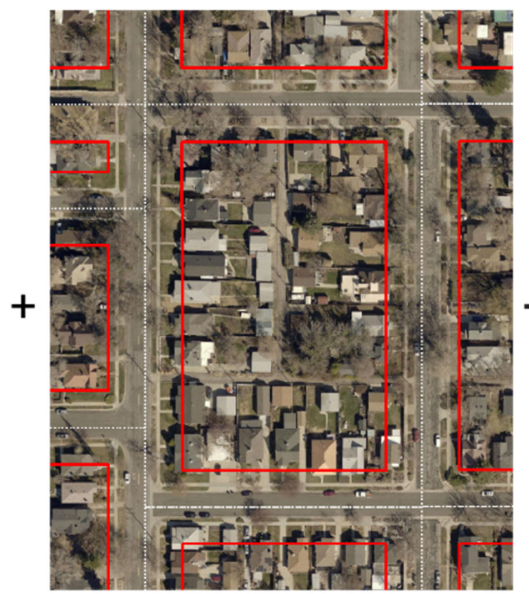

(2) Road centerlines (white) and buffers (red)

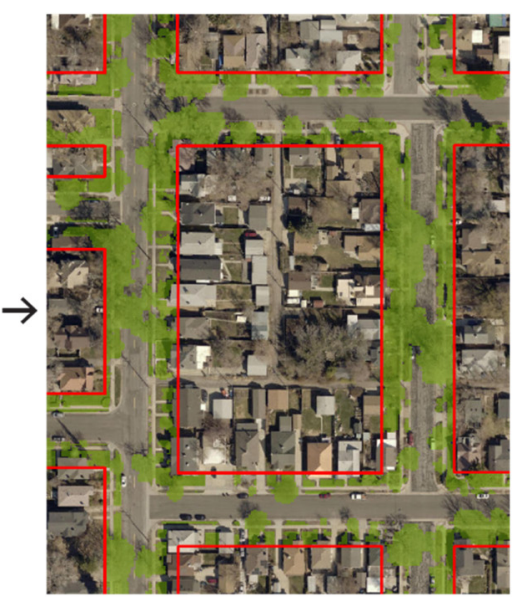

(3) Street greenery

Figure 2. Street greenery extraction using vegetation raster images and road buffers.

\subsubsection{S-L and XL Green Spaces}

In U.S. cities and other Global North contexts, the most typical type of urban green space larger than street greenery (XS) is the urban park (S-XL) [21]. Different organizations and scholars have classified urban parks by their size and function. Table 2 shows examples of park classifications in different countries, highlighting the variations in terminology and size criteria. Such variations are inevitable, because park classifications are often the basis of park and open space planning (e.g., a standard for per capita park acreage), and each community has different recourses and demands [72]. Although parks of various sizes individually play an important role in serving different social needs, large parks have received special attention, given their complexity in programs, ecology, and relation to abutting urban environments [73]. While smaller parks might be designed with a focus on the facilities and amenities needed in the local communities, large parks containing a variety of natural habitats and vegetation provide a unique natural experience [15] and improved social, health, and environmental benefits $[14,16,17]$. Thus, in this study, we separately examine access to neighborhood parks (S-L) and large nature $(\mathrm{XL})$.

A typical size threshold separating large parks from smaller, neighborhood-level parks ranges between 10 to 50 acres ( 4 to 20 hectares). Following the example of a U.S. national investigation of neighborhood park use [74], we used an upper-bound size limit of 20 acres (8.1 hectares) to define neighborhood parks, and thus operationalized large parks as those with an area equal to or bigger than 20 acres. We collected park data from the ParkServe ${ }^{\circledR}$ dataset, which the Trust For Public Land [75] compiled by surveying thousands of municipalities, counties, and states in the U.S. This database includes a variety of green spaces, ranging from local parks to national parks. We first selected publicly-accessible green spaces from the database. Subsequently, we classified S-L green spaces as those that are less than 20 acres in size, and classified XL green spaces as those with an area of 20 acres or more. 
Table 2. Classification of urban green space in different countries.

\begin{tabular}{|c|c|c|c|}
\hline Country & Source & Type & Size Criteria \\
\hline \multirow{4}{*}{ United States } & \multirow{4}{*}{$\begin{array}{l}\text { National Recreation and } \\
\text { Park Association } \\
\text { (Mertes and Hall, 1995) }\end{array}$} & Mini park & $0.4-2$ ha ( $1-5$ acres) \\
\hline & & Neighborhood park & $2-4$ ha (5-10 acres) \\
\hline & & Community park & $8-20$ ha (20-50 acres) \\
\hline & & National resource area, etc. & variable \\
\hline \multirow{6}{*}{ United Kingdom } & \multirow{6}{*}{$\begin{array}{l}\text { Greater London } \\
\text { Authority (2016) }\end{array}$} & Pocket parks & under 0.4 ha ( 1 acre) \\
\hline & & Small open spaces & under 2 ha (1-5 acres) \\
\hline & & Local parks and open spaces & 2 ha (5 acres) \\
\hline & & District parks & 20 ha (50 acres) \\
\hline & & Metropolitan Parks & 60 ha (150 acres) \\
\hline & & Regional parks & 400 ha (1000 acres) \\
\hline \multirow{5}{*}{ Canada } & \multirow{5}{*}{ City of Toronto (2013) } & Parkettes & under 0.5 ha (1.2 acres) \\
\hline & & Neighbourhood Parks & over 0.5 ha (1.2 acres) \\
\hline & & Community parks & over 3 ha ( 7.4 acres) \\
\hline & & District parks & over 5 ha (12.4 acres) \\
\hline & & City parks & over 15 ha (37.1 acres) \\
\hline
\end{tabular}

\subsection{Dependent Variables: Accessibility to Green Spaces}

The transportation modes that people use to access XS, S-L, and XL urban nature are likely to vary. Street greenery (XS nature) is a nearby green space that does not necessarily represent a destination in the same way as larger types of green space, and thus most studies have measured the total area or density of street-level vegetation in a neighborhood or other bounded geographies, likely accessed by walking [25,76]. To access neighborhood parks (S-L nature), urban residents most likely either walk or use a personal vehicle [45,47,77-79]. For example, Derose et al. [77] found that, in Los Angeles, $42 \%$ of survey respondents usually walked to get to a neighborhood park, while $54 \%$ came in a car and $4 \%$ biked. The access mode choice varies depending on race/ethnicity and socioeconomic status, such as car ownership. Derose et al. [77] showed that Latinos/as were more likely to walk to parks than other racial/ethnic groups (51\% vs. 38\%). Similarly, Loukaitou-Sideris and Stieglitz [45] found that more children living in marginalized inner-city areas walked, biked, or used skateboards to access parks, whereas those in more affluent suburban communities tended to drive a car to reach parks. In the case of large parks (XL nature), private vehicles and public transit are more common access modes $[47,80,81]$. Such a discrepancy in access modes to urban green space reveals the limitation of conventional park accessibility studies which exclusively focus on walking, and requires a multimodal approach to measure access to green space.

Thus, in this study, we employed six accessibility measured defined by green spaces of various sizes and different travel modes (Table 3). We used a variation of the container approach, which measures how much green spaces is within reach, and is widely employed across the literature [21,82]. Accordingly, we measured the XS green space accessibility as the density of street greenery in a block group-the area of green pixels within 100 feet $(30.48 \mathrm{~m})$ for arterials and 50 feet $(15.24 \mathrm{~m})$ for local roads divided by the block group area. We measured S-L green space accessibility using walking and bicycling as base travel modes, with an assumption that neighborhood parks primarily serve nearby communities. S-L nature accessible by walking describes the total park acreage in a 10 min walking distance ( 0.5 miles), and the one accessible by bicycling shows the total park acreage in a 10 min bicycling distance ( 2 miles). Ten minutes are commonly considered as a desirable travel time threshold for neighborhood parks, as also shown by a park advocacy initiative in the U.S. named the '10 Minute Walk' campaign (https://10minutewalk.org/). Lastly, we computed three accessibility measures to XL green spaces 
based on walking, bicycling, and driving. XL nature accessed by walking and bicycling was estimated using the same logic and thresholds used for accessibility measures for S-L green spaces- the total park acreage in 0.5 miles for walking and 2 miles for bicycling, respectively. Similarly, we measured the XL park acreage accessed by driving using a 20-min driving distance (20 miles with $60 \mathrm{mph}$ speed). The 20-min threshold was chosen because, according to the 2017 National Household Travel Survey, the average car travel time for recreational activities was $23 \mathrm{~min}$. All of the travel distances were calculated using the network analyst tool in ArcGIS Pro. The boxplots in Appendix A show regional variances in green space accessibility.

Table 3. Variables included in the statistical model.

\begin{tabular}{|c|c|c|c|c|}
\hline Type & Construct & Name & Definition & Level \\
\hline \multirow{6}{*}{$\begin{array}{l}\text { Dependent } \\
\text { variables }\end{array}$} & $\begin{array}{l}\text { Accessibility to XS green } \\
\text { spaces by walking }\end{array}$ & XS & $\begin{array}{c}\text { Density of publicly accessible } \\
\text { street greenery in a } \\
\text { neighborhood }\end{array}$ & Block Group \\
\hline & $\begin{array}{l}\text { Accessibility to S-L green } \\
\text { spaces by walking }\end{array}$ & S-L_walk & $\begin{array}{c}\text { Acreage of S-L parks } \\
\text { (<20 acres) within } 0.5 \text { mile } \\
\text { network distance }\end{array}$ & Block Group \\
\hline & $\begin{array}{l}\text { Accessibility to } \mathrm{S}-\mathrm{L} \text { green } \\
\text { spaces by biking }\end{array}$ & S-L_bike & $\begin{array}{c}\text { Acreage of S-L parks } \\
(<20 \text { acres) within } 2 \text { mile } \\
\text { network distance }\end{array}$ & Block Group \\
\hline & $\begin{array}{l}\text { Accessibility to } \mathrm{XL} \text { green } \\
\text { spaces by walking }\end{array}$ & XL_walk & $\begin{array}{c}\text { Acreage of XL parks } \\
(\geq 20 \text { acres) within } 0.5 \text { mile } \\
\text { network distance }\end{array}$ & Block Group \\
\hline & $\begin{array}{l}\text { Accessibility to } \mathrm{XL} \text { green } \\
\text { spaces by biking }\end{array}$ & XL_bike & $\begin{array}{l}\text { Acreage of XL parks } \\
(\geq 20 \text { acres) within } 2 \text { mile } \\
\text { network distance }\end{array}$ & Block Group \\
\hline & $\begin{array}{l}\text { Accessibility to } \mathrm{XL} \text { green } \\
\text { spaces by driving }\end{array}$ & XL_drive & $\begin{array}{c}\text { Acreage of XL parks } \\
(\geq 20 \text { acres) within } 20 \text { mile } \\
\text { network distance }\end{array}$ & Block Group \\
\hline \multirow{7}{*}{$\begin{array}{l}\text { Independent } \\
\text { variables }\end{array}$} & \multirow{3}{*}{ Race and ethnicity } & Percent NH Black & $\begin{array}{l}\text { Percentage of non-Hispanic } \\
\text { Black population }\end{array}$ & Block Group \\
\hline & & Percent NH Asian & $\begin{array}{l}\text { Percentage of non-Hispanic } \\
\text { Asian population }\end{array}$ & Block Group \\
\hline & & Percent Latino/a & $\begin{array}{l}\text { Percentage of Latino/a } \\
\text { population }\end{array}$ & Block Group \\
\hline & \multirow[b]{2}{*}{ Socioeconomic status (SES) } & Med HH Inc & Median household income & Block Group \\
\hline & & Percent College & $\begin{array}{l}\text { Percentage of people with a } \\
\text { bachelor's degree or higher }\end{array}$ & Block Group \\
\hline & \multirow{2}{*}{ Age } & Percent Child & $\begin{array}{l}\text { Percentage of children } \\
(<18 \text { years })\end{array}$ & Block Group \\
\hline & & Percent Older & $\begin{array}{l}\text { Percentage of older adults } \\
\text { ( } \geq 65 \text { years) }\end{array}$ & Block Group \\
\hline \multirow{4}{*}{\multicolumn{2}{|c|}{ Control variables }} & Pop Den & Population per square mile & Block Group \\
\hline & & Reg Pop Den & $\begin{array}{l}\text { Population per square mile } \\
\text { in a region }\end{array}$ & Urban Area \\
\hline & & Reg Med HH Inc & $\begin{array}{l}\text { Median household income } \\
\text { in a region }\end{array}$ & Urban Area \\
\hline & & $\begin{array}{l}\text { Reg Percent NH } \\
\text { White }\end{array}$ & $\begin{array}{l}\text { Percentage of non-Hispanic } \\
\text { White population in a region }\end{array}$ & Urban Area \\
\hline
\end{tabular}

\subsection{Independent Variables: Sociodemographic Characteristics}

We focus on three constructs that define marginalized groups that might be affected by environmental injustices: race and ethnicity, socioeconomic status (SES), and age (Table 3). Recent definitions of environmental justice require a more comprehensive fair treatment of all people 
regardless of race, color, national origin, income, and educational attainment [83-85]. Further, the environmental justice literature has increasingly incorporated age as a variable of interest, arguing that children and older adults need particularly easy access to environmental amenities $[25,86]$. As noted in the introduction, we considered distributions of green space as just if a marginalized group (e.g., low-SES or racial/ethnic minority people) had better access to green space than the corresponding privileged group (e.g., high-SES or non-Hispanic white people), and as unjust if the opposite happened. Instances wherein no difference existed between marginalized and privileged group were considered as equal distribution, which, in the context of marginalized groups' high need for public green space $[37,55]$, does not constitute a just outcome.

To measure race and ethnicity, SES, and age, we used the 2018 American Community Survey (5-year estimates) as a sociodemographic data source for the 12 urban areas. First, we calculated three variables for race/ethnicity, representing minority populations: the percentage of the Non-Hispanic Black population, the percentage of the Non-Hispanic Asian population, and the percentage of the Latino/a population. Black communities have a history of racial discrimination, with evidence showing environmental injustices such as greater exposure to environmental hazards (flooding: [87]) and poorer access to urban amenities (parks: [31]; trees and shrubs: [24]). The recent instances of police brutality against Black people in the U.S., such as the killing of George Floyd, show evidence that structural racism is still prevalent in the country (see $[50,88]$ ). Also, although Asian people are a fast-growing minority group in the U.S., only a few studies have incorporated them into the environmental justice framework and revealed greater health risks than non-Hispanic white people [89-91]. Latino/a residents, representing one-sixth of the U.S. population, are also more likely than non-Hispanic white people to live areas with higher exposure to pollutants [92], higher crime rates [93] and smaller parks [52,93]. We did not include other racial and ethnicity groups (e.g., American Indian and Alaska Native, Native Hawaiian and Pacific Islander) in this study because their share of the total population is relatively small in the sampled urban areas.

Second, we considered two SES factors: income and educational attainment. We chose the median household income as it efficiently represents the typical level of the economic status of households in a neighborhood, not being affected by the extreme ends of the distribution. For educational attainment, we computed the percentage of people older than 25 years of age with a bachelor's degree or higher.

Lastly, we included two age-related variables: the percentage of people under 18 years of age (children and teenagers) and the percentage of people older than 65 years (older adults). These two age groups have limited mobility and fewer transportation choices than young adults and, thus, might require enhanced accessibility to recreation opportunities and other key destinations. Particularly, seniors and children living in marginalized neighborhoods are likely to have a higher level of obesity [94,95]. Nevertheless, many environmental justice studies focus on adults [96], and some seniors and children experience a lack of access to opportunities (seniors and healthy food: [97]; children and parks: [98]).

In addition to the seven sociodemographic variables of interest, we included several block groupand region-level control variables in our models (Table 3). As our study sample includes urban areas of various sizes and characteristics, it is essential to control for built environment characteristics (region and block group levels) and SES at the regional level. Studies revealed poorer walking access to neighborhood parks in areas with a lower population density [31,32,52]. Furthermore, park acreage is lower in cities with lower SES, and the quality of urban park systems is lower in cities with higher percentages of minority residents [52,99]. Thus, at the regional level, we included population density, median household income, and the percentage of non-Hispanic white people as control variables. Additionally, we incorporated a block-level population density variable to account for within-region variance in density. Table 1 (urban area level) and Table 4 (block group-level) show the averages of variables included in this study. 
Table 4. Block-group-level averages of sociodemographic variables by urban area.

\begin{tabular}{|c|c|c|c|c|c|c|c|c|c|}
\hline Urban Area & $\begin{array}{l}\text { \# Block } \\
\text { Groups }\end{array}$ & $\begin{array}{c}\text { Percent NH } \\
\text { Black (\%) }\end{array}$ & $\begin{array}{c}\text { Percent NH } \\
\text { Asian (\%) }\end{array}$ & $\begin{array}{c}\text { Percent } \\
\text { Latino/a (\%) }\end{array}$ & $\begin{array}{c}\text { Med } \\
\text { HH Inc }\end{array}$ & $\begin{array}{c}\text { Percent } \\
\text { Bachelor } \\
(\%)\end{array}$ & $\begin{array}{l}\text { Percent } \\
\text { Child (\%) }\end{array}$ & $\begin{array}{l}\text { Percent } \\
\text { Older (\%) }\end{array}$ & Pop Den \\
\hline Seattle & 2153 & $6 \%$ & $13 \%$ & $10 \%$ & 91,312 & $43 \%$ & $21 \%$ & $14 \%$ & 6852 \\
\hline Salt Lake City & 600 & $2 \%$ & $4 \%$ & $18 \%$ & 75,413 & $35 \%$ & $25 \%$ & $12 \%$ & 6022 \\
\hline Fresno & 390 & $6 \%$ & $11 \%$ & $47 \%$ & 54,749 & $21 \%$ & $27 \%$ & $13 \%$ & 6373 \\
\hline Minneapolis & 1907 & $10 \%$ & $7 \%$ & $7 \%$ & 80,476 & $44 \%$ & $22 \%$ & $14 \%$ & 5352 \\
\hline Kansas City & 1130 & $18 \%$ & $3 \%$ & $12 \%$ & 65,886 & $35 \%$ & $23 \%$ & $14 \%$ & 3679 \\
\hline Grand Rapids & 356 & $11 \%$ & $3 \%$ & $12 \%$ & 61,271 & $34 \%$ & $24 \%$ & $13 \%$ & 4338 \\
\hline Houston & 2352 & $18 \%$ & $7 \%$ & $41 \%$ & 70,550 & $30 \%$ & $25 \%$ & $11 \%$ & 6392 \\
\hline Raleigh & 407 & $19 \%$ & $6 \%$ & $9 \%$ & 82,361 & $52 \%$ & $22 \%$ & $13 \%$ & 3063 \\
\hline Sarasota & 431 & $6 \%$ & $2 \%$ & $12 \%$ & 58,256 & $31 \%$ & $14 \%$ & $36 \%$ & 3120 \\
\hline Boston & 3008 & $8 \%$ & $8 \%$ & $12 \%$ & 95,001 & $48 \%$ & $20 \%$ & $15 \%$ & 10,956 \\
\hline Providence & 864 & $6 \%$ & $3 \%$ & $14 \%$ & 66,719 & $31 \%$ & $20 \%$ & $17 \%$ & 6578 \\
\hline Buffalo & 787 & $17 \%$ & $3 \%$ & $6 \%$ & 54,645 & $30 \%$ & $20 \%$ & $17 \%$ & 6129 \\
\hline
\end{tabular}

\subsection{Data Analysis: Spatial Filtering Regression Models}

We modeled each green space accessibility measure as a function of sociodemographic variables of interest and other control variables (Table 3). Our study sample consists of neighborhoods from 12 regions, and the neighborhoods in a region share similar regional characteristics (e.g., compactness, climate, transportation network). Thus, to represent the nested structure of the sample, we employed multi-level models, with block groups at Level 1 and the urban area at Level 2. For example, a modeling equation for the XS variable is as follows:

$$
\begin{gathered}
X S_{i j}=\beta_{0 j}+\beta_{1 j} \text { Race }_{i j}+\beta_{2 j} \text { Socioeconomic }_{i j}+\beta_{3 j} \text { Age }_{i j}+\beta_{4 j} \text { Control }_{i j}+\varepsilon_{i j} \\
\beta_{0 j}=\gamma_{00}+\gamma_{01} \text { Control }_{j}+u_{0 j} ; \\
\beta_{1 j}=\gamma_{10}+u_{1 j} ; \beta_{2 j}=\gamma_{20}+u_{2 j} ; \beta_{3 j}=\gamma_{30}+u_{3 j} ; \beta_{4 j}=\gamma_{40}+u_{4 j}
\end{gathered}
$$

where $X S_{i j}$ refers to the accessibility to XS green space for block group $i$ in region $j$, and $\beta_{0 j}$ is the intercept of the dependent variable in region $j . \beta_{1 j}$ and $R a e_{i j}$ represent a set of race/ethnicity-related coefficients and variables, respectively, for block group $i$ in region $j$. Similarly, $\beta_{2 j}$ and Socioeconomic $i j$ indicate coefficients and variables of income and educational attainment, $\beta_{3 j}$ and $A g e_{i j}$ are components of children and senior population, and $\beta_{4 j}$ and $\mathrm{Control}_{i j}$ are for a block-group-level control variable we included. $\varepsilon_{i j}$ is the block group level residual. The intercept in the Level 1 equation $\left(\beta_{0 j}\right)$ consists of the level 2 intercept for each covariate $\left(\gamma_{00}\right)$, the level 2 coefficient $\left(\gamma_{01}\right)$ and control variables such as population density and median household income $\left(\right.$ Control $\left._{j}\right)$, and the level 2 residual $\left(u_{j}\right)$.

We examined the presence of spatial autocorrelation in our data through preliminary non-spatial multi-level regression models. When a dataset displays spatial autocorrelation-the tendency where areas close to each other have similar residual values-it violates the assumption of the independence of residuals in regression models and leads to inflated effect sizes. Our preliminary analysis showed spatial autocorrelation; thus, we used spatial filtering approaches that separate the redundant effects of a variable caused by spatial dependency [100]. Spatial filtering finds latent spatial patterns in the independent variables and creates eigenvectors that show the level of spatial autocorrelation [101]. Through this method, we extracted eigenvectors that reduce spatial autocorrelation in the residuals and used them as additional control variables in the regression models [102]. Although there are other modeling approaches capable of addressing spatial autocorrelation—such as spatial lag, spatial error, and geographically weighted regression models—-the spatial filtering technique has three advantages: (1) it can be applied to a generalized linear model specification (e.g., nominal or skewed variables), and is thus more flexible; (2) it has no multicollinearity issues; and (3), most relevant to this study, it allows for multilevel modeling $[100,103]$. 
We ran two sets of models: the main models for the entire sample and individual models for each urban area (also referred to as 'regional models'). We ran all of the models in R 4.0.0. For the main model, we used the meigen and resf functions in the spmoran package to extract Moran's eigenvectors and run spatial regression models with random effect eigenvectors, respectively. For the regional models, we employed the meigen and esf functions in the same package to find eigenvectors and run a linear eigenvector spatial filtering model. Through the spatial filtering approach, we successfully removed the effect of spatial autocorrelation for all of the main and region-wide models. Following Griffith's [100] thresholds for autocorrelation levels, the scaled Moran's I values for the residuals of all of the models only showed slight-to-weak autocorrelation, ranging between 0.01 and 0.29 .

\section{Results}

\subsection{Main Models for the 12 Urban Areas}

Table 5 summarizes the multi-level spatial filtering model results for the 12 urban areas, with shaded cells showing statistically significant results for environmental injustice (orange) and justice (green). The results for access to XS green space show environmental injustices based on race/ethnicity and income. Specifically, wealthier neighborhoods have access to more XS green space, whereas areas with larger percentages of racial/ethnic minority residents (i.e., Hispanic, non-Hispanic Black, and non-Hispanic Asian) have less XS green space. Neighborhoods with a higher share of older adults or children have more street greenery, showing just outcomes for the two examined age subgroups.

Table 5. Multi-level spatial filtering model results for 12 urban areas (dependent variables: green space accessibility).

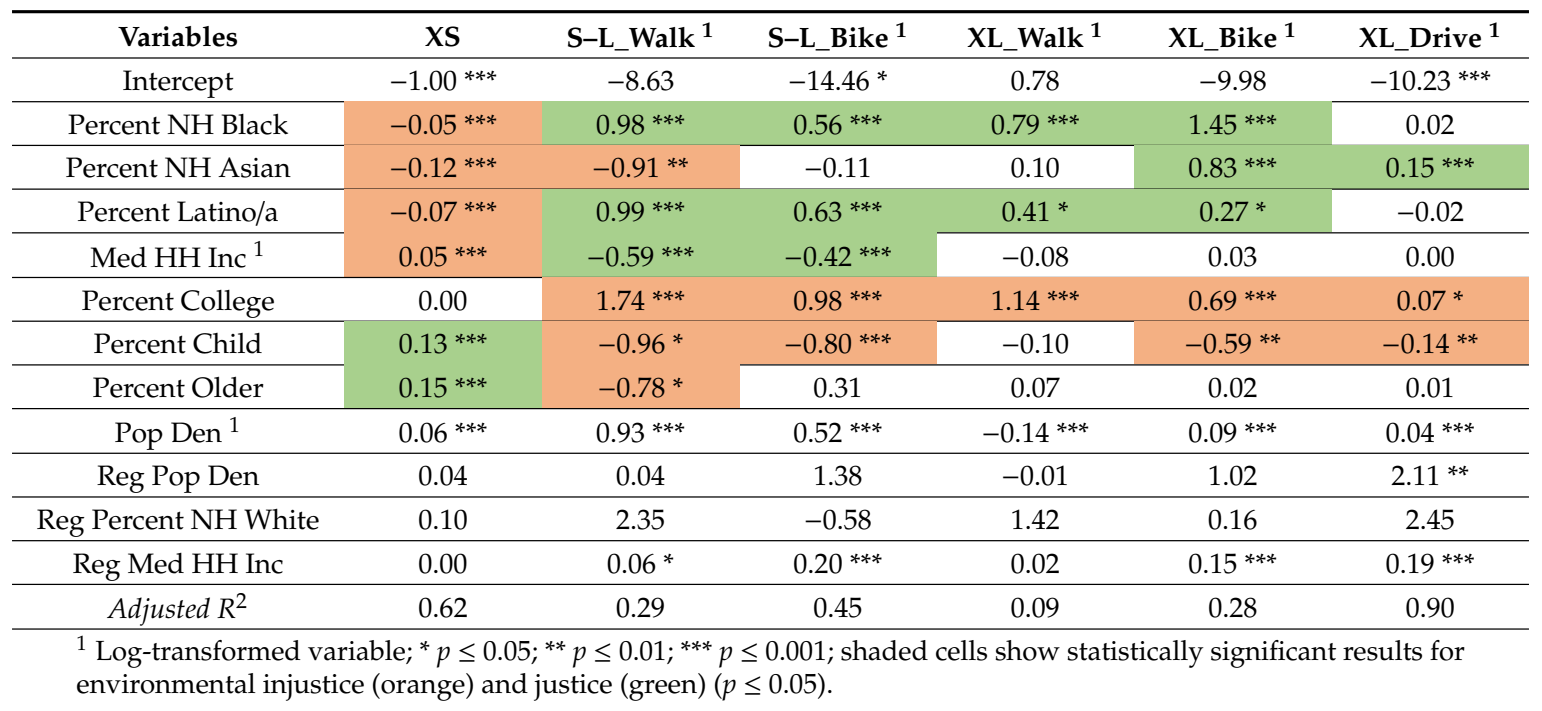

Walking access to S-L parks also shows both environmental justice and injustice outcomes among different sociodemographic variables. Walking access to S-L green space is higher in areas with lower incomes and a larger share of non-Hispanic Black residents or Latino/a residents, showing environmentally just outcomes. However, walking accessibility to S-L green spaces is lower in neighborhoods with larger percentages of non-Hispanic Asians, older adults, or children, showing environmental injustice for those groups. Biking access to S-L green space shows environmentally just outcomes for the percentage of non-Hispanic Black people, the percentage of Latino/a people, and household income, but it also highlights injustice regarding educational attainment and the percentage of children. Indeed, areas with larger shares of college-educated residents and smaller percentages of children have higher bicycling access to S-L green space. 
Walking access to XL parks increases with the percentage of people holding a bachelor's degree or higher, representing injustice related to educational attainment, but also shows an increase with the percentage of non-Hispanic Black and Latino/a people, showing just access to XL green space for these minority groups. Bicycling access to XL green spaces increases with larger shares of college-educated people and smaller shares of children, but larger shares of Black or Asian residents are associated with higher cycling access to XL parks. Driving access to XL green space shows similar patterns; no injustice was found regarding race/ethnicity (larger shares of Asian residents mean higher access), but a larger percentage of college-educated residents and a lower percentage of children are associated with higher driving access to $\mathrm{XL}$ green space.

Population density is statistically significant in all of the main models (see Table 5). All of the XS and S-L accessibility measures were greater in denser neighborhoods, possibly due to more investments in green spaces in areas with more people. On the contrary, walking access to XL green spaces decreases with population density, which is attributable to large parks commonly existing at the fringe of cities, where density is low. Nevertheless, when faster travel modes (bicycling or driving) are available and reachable distances increase, access to $X L$ nature again increases with population density, implying that denser neighborhoods might be located near XL nature.

Regional population density and the percentage of non-Hispanic white people were not significant in any model, except for the positive relationship between regional population density and driving access to $\mathrm{XL}$ nature. This shows that neighborhood-level differences in population density and race/ethnicity matter more for green space accessibility than city-level differences. On the contrary, regional income levels present a positive association with most accessibility measures, except for bicycling access to $\mathrm{XL}$ green spaces, meaning that cities with wealthier residents tend to provide residents with better access to green spaces of various sizes.

\subsection{Regional Models}

Table 6 presents the results of spatial filtering regression models for each urban area. All the examined regions show clearer patterns of environmental justice and injustice in XS greenery accessibility compared to larger-scale accessibility measures. In particular, we found injustices related to race/ethnicity and SES for access to XS nature across almost all regions (see Appendix B for regional model results). Additionally, neighborhoods with larger shares of seniors and children enjoyed better XS greenery access in most regions, indicating just outcomes for these age groups.

In terms of S-L and XL accessibility, environmental (in)justice patterns are less clear. This might be attributable to more systematic provisions of green spaces intended to serve neighborhoods (S-L) and the region $(\mathrm{XL})$ within an urban area, compared to street-level greenery. Nevertheless, bigger cities (e.g., Houston, Minneapolis, Boston) experience injustices associated with race/ethnicity and socioeconomic status. For example, in Minneapolis, all racial/ethnic minority groups have poorer bicycling access to S-L nature. In Boston, areas with larger shares of Asian or Latino/a residents have lower walking access to S-L green space, and areas with larger percentages of Black people have access to less $\mathrm{XL}$ green space within driving distance. 
Table 6. Environmental justice and injustice types ${ }^{1}$ in regional models of green space accessibility ${ }^{2}$.

\begin{tabular}{|c|c|c|c|c|c|c|c|c|c|}
\hline \multirow{2}{*}{ Urban Area } & \multicolumn{3}{|c|}{ XS } & \multicolumn{3}{|c|}{ S-L_Walk } & \multicolumn{3}{|c|}{ S-L_Bike } \\
\hline & Race $^{3}$ & SES $^{4}$ & Age $^{5}$ & Race & SES & Age & Race & SES & Age \\
\hline Seattle & $\operatorname{InJ}(3)$ & $\operatorname{InJ}(1)$ & $\mathrm{J}(1)$ & & $\mathrm{J}(1)$ & & & & \\
\hline Salt Lake City & $\operatorname{InJ}(3)$ & $\operatorname{InJ}(1)$ & $\mathrm{J}(2)$ & & & & & & \\
\hline Fresno & $\operatorname{InJ}(2)$ & $\operatorname{InJ}(2)$ & $\mathrm{J}(1)$ & & & & & & \\
\hline Minneapolis & $\operatorname{InJ}(3)$ & $\operatorname{Mix}(1 / 1)$ & $\mathrm{J}(1)$ & $\operatorname{InJ}(3)$ & $\mathrm{J}(1)$ & & & & \\
\hline Kansas City & $\operatorname{InJ}(3)$ & $\operatorname{Mix}(1 / 1)$ & $\mathrm{J}(2)$ & & & $\operatorname{InJ}(1)$ & & $\mathrm{J}(1)$ & \\
\hline Grand Rapids & $\operatorname{InJ}(1)$ & $\operatorname{InJ}(1)$ & $\mathrm{J}(1)$ & & & & & & \\
\hline Houston & $\operatorname{InJ}(3)$ & $\operatorname{Mix}(1 / 1)$ & $\mathrm{J}(2)$ & & $\operatorname{InJ}(1)$ & & $\operatorname{InJ}(2)$ & & \\
\hline Raleigh & $\operatorname{InJ}(1)$ & $\operatorname{InJ}(1)$ & $\mathrm{J}(1)$ & & & & & & \\
\hline Sarasota & $\operatorname{InJ}(2)$ & $\operatorname{InJ}(1)$ & $\operatorname{InJ}(1)$ & & & & & & \\
\hline Boston & $\operatorname{InJ}(3)$ & $\operatorname{InJ}(2)$ & $\mathrm{J}(2)$ & $\operatorname{InJ}(2)$ & $\mathrm{J}(1)$ & & & & $\mathrm{J}(1)$ \\
\hline Providence & $\operatorname{InJ}(3)$ & $\operatorname{InJ}(2)$ & $\mathrm{J}(1)$ & & $\mathrm{J}(1)$ & & & & \\
\hline Buffalo & $\operatorname{InJ}(2)$ & $\operatorname{InJ}(2)$ & $\mathrm{J}(1)$ & & & & & & \\
\hline $\begin{array}{l}\text { Total InJ types } \\
\text { by EJ construct }\end{array}$ & 29 & 16 & 1 & 5 & 1 & 1 & 2 & 0 & 0 \\
\hline \multirow{2}{*}{ Urban Area } & \multicolumn{3}{|c|}{ XL_walk } & \multicolumn{3}{|c|}{ XL_drive } & \multicolumn{3}{|c|}{ Total InJ types by city } \\
\hline & Race & SES & Age & Race & SES & Age & Race & SES & Age \\
\hline Seattle & & & & & & & 3 & 1 & 0 \\
\hline Salt Lake City & & & & & & & 3 & 1 & 0 \\
\hline Fresno & & & & & & & 2 & 2 & 0 \\
\hline Minneapolis & & $\operatorname{InJ}(1)$ & & & & & 6 & 2 & 0 \\
\hline Kansas City & & & & & & & 3 & 1 & 1 \\
\hline Grand Rapids & & & & & & & 1 & 1 & 0 \\
\hline Houston & $\mathrm{J}(1)$ & & & $\operatorname{InJ}(1)$ & & & 6 & 2 & 0 \\
\hline Raleigh & $\mathrm{J}(1)$ & $\operatorname{InJ}(1)$ & & & & $\mathrm{J}(1)$ & 1 & 2 & 0 \\
\hline Sarasota & & & & & & & 2 & 1 & 1 \\
\hline Boston & & $\mathrm{J}(1)$ & & $\operatorname{InJ}(1)$ & $\mathrm{J}(1)$ & $\operatorname{Mix}(1 / 1)$ & 6 & 2 & 1 \\
\hline Providence & & & & & & & 3 & 2 & 0 \\
\hline Buffalo & & & $\mathrm{J}(1)$ & & & & 2 & 2 & 0 \\
\hline $\begin{array}{l}\text { Total InJ types } \\
\text { by EJ construct }\end{array}$ & 0 & 2 & 0 & 2 & 0 & 1 & 38 & 19 & 3 \\
\hline
\end{tabular}

${ }_{1} \mathrm{~J}(\#)$ refers to the presence and number of a just relationship(s), InJ(\#) means the presence and number of an unjust relationship(s), and Mix(J\#/InJ\#) is a combination of J and InJ relationship(s). ${ }^{2}$ Results from XL bike models are not shown because they rarely have statistically significant coefficients across 12 models. ${ }^{3}$ Race/ethnicity variables: $\%$ of non-Hispanic Black population, \% of non-Hispanic Asian population, and \% of Latino/a population. ${ }^{4}$ Socioeconomic status variables: Median household income, \% of people with a bachelor's degree or higher. ${ }^{5}$ age-group variables: $\%$ of child population ( $<18$ years), $\%$ of older adult population ( $\geq 65$ years). Shaded cells show statistically significant results for environmental injustice (orange) and justice (green) $(p \leq 0.05)$.

\section{Discussion and Conclusions}

\subsection{Summary of Findings}

In this study, we evaluated green space accessibility in 12 urban areas in the U.S. based on the 'just sustainabilities' framework. Access to green spaces promotes urban residents' quality of life and contributes to the creation of just and sustainable cities [53-55]. However, green spaces of different sizes might have diverse environmental and health benefits $[1,3,18]$. Thus, we distinguished three types of urban nature (XS, street greenery; S-L, neighborhood parks; and XL, large parks), measured six different green space accessibility variables defined by three travel modes (walking, bicycling and driving), and examined whether access to those green spaces is environmentally just, using neighborhoods' racial/ethnic, socioeconomic, and age characteristics as indicators for potential just or unjust access. 
Our results from spatial filtering models across the 12 urban areas show that significantly less street greenery $(X S)$ is available to racial/ethnic minority groups (e.g., Black, Asian, and Latino/a) and low-income residents, as is consistent with earlier studies [24,25,27]. This pattern of injustice is also found in most regional models, representing prevalent race/ethnicity-based and income-based injustice in 'everyday green' across the country. Research has shown that volunteer groups and nonprofit organizations might contribute to injustices in tree canopy cover, as those groups tend to be more active in affluent non-Hispanic white neighborhoods than in low-income minority communities [61,104]. Further, our results on XS nature can be tied to the ongoing legacy of structural racism in the U.S. A recent study shows that neighborhoods that were 'redlined' (i.e., targeted for disinvestment by banks) starting in the 1930s have $21 \%$ less tree canopy cover than neighborhoods that banks deemed desirable, on average [50]. Redlined neighborhoods were, and still are, mostly inhabited by low-income people of color $[33,50,105]$. Due in part to their lower tree canopy cover, redlined areas tend to be hotter and more vulnerable to extreme heat events than other neighborhoods [105].

Unlike access to street greenery, results about access to neighborhood parks (S-L) display more just patterns across the examined regions in terms of race/ethnicity (except for the percentage of Asians) and income level. Nevertheless, regional models highlight that some bigger regions (e.g., Minneapolis, Houston and Boston) experience racial/ethnic or income injustices in access to neighborhood parks. Furthermore, the main models with the 12 cities show that neighborhoods with larger shares of educated people, smaller shares of children, or smaller shares of seniors tend to have better access to neighborhood parks, regardless of travel mode. Overall, our results for neighborhood parks do not reflect those of two recent literature reviews focusing on such parks in the Global North and Global South, which show consistent injustices in park acreage based on race/ethnicity and socioeconomic status [21,22]. Our results are more aligned with those of a recent empirical study focusing on 10 U.S. cities, finding mixed results for socioeconomic status and race/ethnicity [25]. These discrepancies might be because, like Nesbitt et al. [25], we control for several possible confounders (e.g., population density), whereas many studies included in the two aforementioned reviews did not account for such confounders (see [21,22]).

Our main models on access to large parks (XL) show similar patterns of environmental (in)justice: more instances of just access in terms of race/ethnicity, but also injustices associated with educational attainment and the share of children. Regional models present more nuanced findings, illustrating access to large parks and related environmental justice issues greatly depend on which region people live in. For example, in Houston and Boston, neighborhoods with larger shares of Black people have poorer driving access to large parks. Our findings somewhat conflict with the few available studies on access to large parks, which have shown some injustices based on race/ethnicity and socioeconomic status (e.g., [31,32,34]). As for the divergent findings for S-L nature, in the current study, we control for possible confounders (e.g., population density), whereas many previous studies on XL nature did not. Thus, previous studies might have found injustices in access to large parks because higher shares of affluent and non-Hispanic white people live in areas with low population density (often at the edges of urban areas), where many large parks are located.

\subsection{Access to Green Space and 'Just Sustainabilities'}

Taken together, the findings of the present study advance our understanding of just sustainabilities in relation to urban green space. Here, we focus on how our findings on environmental (in)justice intersect with the 'just sustainabilities' conditions [35] that more closely relate to the concept of sustainability: ensuring that the needs of current and future generations are met, and living within the limits of our planet's ecosystems. Specifically, green spaces of different sizes and types can provide diverse ecosystem services and other environmental benefits [106-108]. Thus, the findings of this study shed light on which demographic groups gain more environmental benefits from green spaces of different sizes, linking an analysis of environmental justice to environmental sustainability. 
First, trees are considered to be a planning tool to slow down climate change and mitigate its negative impacts $[109,110]$, and the consistent injustices we found for XS green space (representing street greenery including trees) are concerning in that regard. Indeed, the injustices of street greenery we identified in our study, combined with other environmental and economic injustices, might help explain that people of color and low-income people experience disproportionate impacts from climate change [59]. For example, marginalized groups tend to be more exposed to extreme heat and air pollutants than privileged groups, and trees can help mitigate the harmful impacts by lowering the local temperature and improving air quality $[9,59,105]$.

Second, the mixed findings for S-L and XL nature-i.e., justice for some racial/ethnic minority groups and injustice based on educational attainment and age-are more reassuring for 'just sustainabilities' than the results for XS nature. Specifically, park size is associated with lower temperatures in surrounding areas $[107,111,112]$ and increased ecological diversity $[13,15]$; thus, large parks (XL nature) bring more environmental benefits to nearby areas than neighborhood parks (S-L nature). Based on our results on walking access to large parks, non-Hispanic Black and Asian people might gain disproportionately large shares of these environmental benefits and related health benefits (just outcomes), which might contribute to addressing the health inequities borne by Black people in the U.S. (see [40]). However, people without a college degree and people under 18 years of age might have disproportionately low shares of the environmental and health benefits of S-L and XL nature (unjust outcomes).

Overall, the notable environmental injustices in the access to XS nature are the most problematic for 'just sustainabilities.' Indeed, street greenery represents nearby nature that should be the easiest to implement-i.e., all neighborhoods have streets where trees can be planted-whereas parks (and large parks specifically) are much more complicated to build in mature neighborhoods. Additionally, street greenery represents the 'everyday green' that people can experience without the need to travel to a destination (e.g., a neighborhood park), and thus XS nature can impact the quality of life significantly $[20,113]$. Furthermore, the acceleration of climate change makes street trees and greenery in marginalized neighborhoods fundamental tools for climate justice [114].

\subsection{Strengths, Limitations, and Future Research}

A primary strength of this study lies in its comprehensive analysis of access to green space through the 'just sustainabilities' framework, thus considering the intersections of justice and environmental sustainability. This study adds to the park accessibility literature by analyzing multiple scales of green spaces-from XS (street greenery) to XL (large parks) - in several urban areas across the U.S. Beyond studying walking access to neighborhood parks (e.g., a 10-min walk; https://10minutewalk.org/), our analyses also cover bicycling and driving access to larger parks, as well as a daily dose of urban nature at the street level. The latter (XS nature) may be enjoyed sensibly (mostly visually) through any mode of transportation when someone travels around their neighborhood. Examining the accessibility to different scales of green spaces via different travel modes can both advance our understanding of distributional (in)justice outcomes and help green space organizations to develop strategies to address injustices.

The use of multi-level spatial filtering models is another strength of our analyses. Previous studies about inequity in access to parks mostly relied on exploratory spatial analyses [24,31-34] or spatial regression models with a spatial lag or error term $[25,26,28,30]$. The multi-level spatial regression models we use can address the spatial clustering effect of green space access within a region while separating between-region variations from within-region variations. Spatial filtering is particularly useful when the dependent variable, a measure of green space accessibility, is not normally distributed (e.g., positively skewed, a large number of zero values), as it was the case in our data [100].

Our study entails several limitations that can be addressed in future research. First, we did not consider green space quality, including the presence of amenities and tree canopy in parks, and quality has increasingly been studied as a key aspect of environmental justice (e.g., [32,115]). 
Second, different demographic groups tend to have various levels of mobility, mode choice, and safety barriers for some transportation modes. In particular, 'transportation disadvantaged' individuals (e.g., people with disabilities, low-income people, seniors, children) may lack access to personal automobiles and rely more on other transportation modes, such as public transit or paratransit to get to urban nature [116]. Further, Black and Latino/a people in the U.S. are significantly more likely to be killed in cycling crashes than non-Hispanic white people [117]. Thus, universally-accessible road environments, varying travel thresholds, road safety, and public transit accessibility may be additional considerations in future research about green space access. Third, we did not control for zoning or land use due to differences in land use classifications among the 12 urban areas, and block groups with industrial land uses might have fewer parks [118]. Lastly, in addition to park supply, park demand (i.e., the surface of parks divided by the potential number of park users) might also be an important measure to evaluate environmental justice in green space access. Residents in different neighborhoods might compete for the same green space, especially regional parks (i.e., XL nature). High levels of crowding in a green space may be particularly harmful when people try to maintain social distancing in public space during a pandemic (e.g., COVID-19: [119]). Thus, beyond our 'absolute accessibility' measures, future work could also focus on 'relative accessibility' to green space, which is measured by standardizing green space quantity by population size $[120,121]$.

\subsection{Implications}

This study has a series of implications for urban planners, policymakers, and green space advocates. First, our results show that environmental justice outcomes vary by green space size. In other words, green space size matters for justice outcomes, and planning efforts to address injustices need to consider each city's existing access to XS, S-L, and XL green spaces. For example, we found that Minneapolis experiences racial/ethnic-based injustices for XS and S-L green space, but not for XL green space. Justice-oriented efforts to improve access to green space in racial/ethnic minority neighborhoods in that city should focus on street greenery (XS) and neighborhood parks (S-L). Thus, the results of our study suggest that the first important step to reverse environmental injustices for green spaces is analyzing for which types of green space injustices exist.

Second, we found that environmental injustices in street greenery (XS green space) are the most consistent across the 12 cities we studied. Cities around the world have recently implemented tree planting initiatives, motivated in part by climate change mitigation goals [122,123]. Specifically, programs in New York (MillionTreesNYC) and Los Angeles (MillionTreesLA) aimed to plant one million trees in areas with low levels of tree canopy [122,123]. However, only Los Angeles' program moved the needle toward environmental justice, as more trees were planted in racial/ethnic minority neighborhoods than in non-Hispanic white neighborhoods [122]. This shows that these programs need to have clear criteria about socioeconomic status, race/ethnicity, and even age to ensure that the existing injustices are addressed [122]. Furthermore, although research has shown that nonprofit organizations have contributed to increased injustices in tree canopy cover in some cities [61,104], some nonprofits in Los Angeles are doing just the opposite, by planting trees in marginalized communities [124]. Thus, public agencies that distribute grants to urban forestry nonprofits (see [125]) should prioritize nonprofits working in low-income communities of color to help reverse the legacies of structural racism regarding tree canopy cover.

Third, we also found some injustices for neighborhood parks (S-L) and large parks (XL), although they are less frequent than for street greenery (XS) across our sample of 12 cities. Effective work to address injustices in access to neighborhood parks has included public agencies prioritizing funding in low-income, park-poor communities [37] and nonprofits using sophisticated strategies to build new parks in such communities [55]. Furthermore, because building large parks is much harder than neighborhood parks due to the difficulty of securing large plots of land in mature neighborhoods, possible solutions include tailored transportation services, such as transit-to-parks programs (see [126]). 
Yet we urge policymakers, planners, and advocates, to prioritize efforts to increase walking access to green spaces, as most of their environmental benefits are detected in their proximity (see [127]).

Finally, green space programs motivated by environmental sustainability alone, without concerns about 'just sustainabilities,' are likely to result in unjust outcomes for marginalized people, as shown by research on the 'sustainability fix' (see [128]). Specifically, 'sustainability fix' initiatives tend to prioritize the values of elected officials, business groups, and lobby groups over those of marginalized communities, such as low-income people and people of color [128]. As a result, urban greening initiatives, such as the construction of new parks and tree plantings in low-income and racial/ethnic minority neighborhoods, have resulted in green gentrification, which describes the influx of new wealthier residents and the increase in housing prices after greening has been implemented [129-131]. The boomerang of green gentrification shows the importance of using a 'just sustainabilities' approach to urban greening initiatives in marginalized neighborhoods, including coupling greening with initiatives to protect and produce affordable housing for longtime, low-income residents [35].

Author Contributions: Conceptualization, writing —original draft preparation, and writing-review and editing: D.-a.C., K.P., and A.R.; data curation, formal analysis, and investigation: D.-a.C. and K.P.; project administration and visualization: D.-a.C.; Supervision: K.P. and A.R. All authors have read and agreed to the published version of the manuscript. Funding: This research received no external funding.

Conflicts of Interest: The authors declare no conflict of interest.

\section{Appendix A. Green Space Accessibility by Urban Area}

The observed green space accessibility measures vary by urban area. With regard to walking and biking access, larger urban areas tend to have a better green space accessibility, on average, but also show greater within-region variation. In addition, driving access to XL green space is noticeably higher in Salt Lake City and Grand Rapids, compared with the other ten regions.
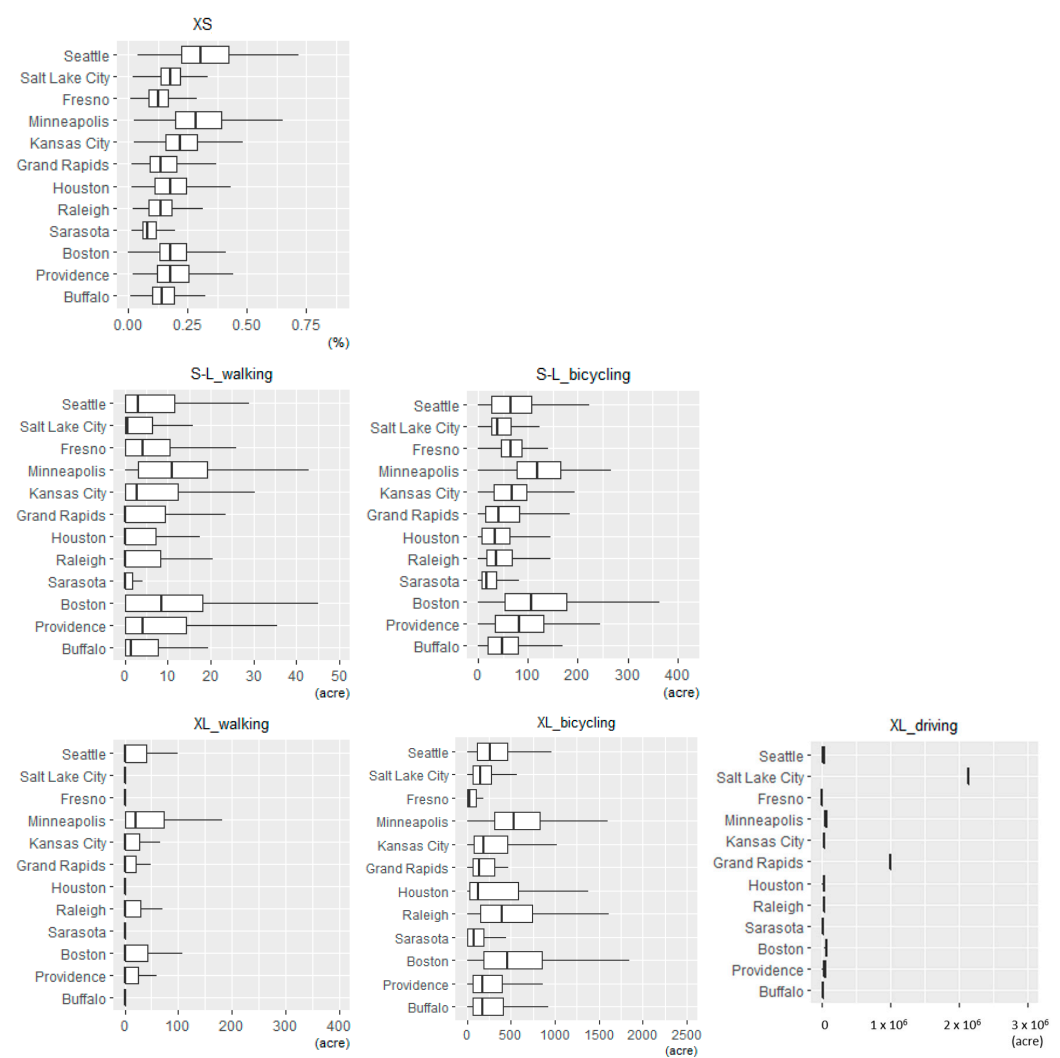

Figure A1. Box plots of XS, S-L, and XL green space accessibility by urban area (some outliers are not present in the graphs because we adjusted the $x$-axis dimensions to highlight regional variables) 


\section{Appendix B. Regional Models}

Table A1. Spatial filtering model results by urban area (cities in West and Midwest regions).

\begin{tabular}{|c|c|c|c|c|c|c|c|c|c|c|c|c|}
\hline \multirow{2}{*}{$\begin{array}{c}\begin{array}{c}\text { Urban } \\
\text { Area }\end{array} \\
\text { Variables }\end{array}$} & \multicolumn{6}{|c|}{ Seattle } & \multicolumn{6}{|c|}{ Minneapolis } \\
\hline & XS & $\begin{array}{l}\text { S-L_ } \\
\text { walk }\end{array}$ & $\begin{array}{l}\text { S-L }{ }_{-} \\
\text {bike }\end{array}$ & $\begin{array}{c}\mathrm{XL}_{-} \\
\text {walk }\end{array}$ & $\begin{array}{l}\mathrm{XL} \\
\text { bike }\end{array}$ & $\begin{array}{c}\mathrm{XL}_{-} \\
\text {drive }\end{array}$ & XS & $\begin{array}{l}\text { S-L } \\
\text { walk }\end{array}$ & $\begin{array}{l}\text { S-L_ } \\
\text { bike }\end{array}$ & $\begin{array}{c}\mathrm{XL}_{-} \\
\text {walk }\end{array}$ & $\begin{array}{l}\mathrm{XL} \\
\text { bike }\end{array}$ & $\begin{array}{c}\mathrm{XL}_{-} \\
\text {drive }\end{array}$ \\
\hline Intercept & $-1.11^{* * *}$ & $-\underset{* * *}{-11.30}$ & $2.61^{* *}$ & $7.52 * * *$ & $5.88^{* * *}$ & $10.23^{* * *}$ & $-1.30^{* * *}$ & $-10.13 * *$ & $4.45^{* * *}$ & -1.62 & $6.62 * * *$ & $11.07^{* * *}$ \\
\hline $\begin{array}{l}\text { Percent } \\
\text { NH Black }\end{array}$ & $-0.08^{* *}$ & -1.53 & -0.37 & -0.64 & -0.64 & -0.17 & $-0.20 * * *$ & $-1.84^{*}$ & -0.22 & -0.13 & -0.20 & -0.03 \\
\hline $\begin{array}{c}\text { Percent } \\
\text { NH Asian }\end{array}$ & $-0.14^{* * *}$ & 0.59 & 0.25 & -0.08 & -0.08 & 0.16 & $-0.18^{* * *}$ & -2.37 * & -0.10 & -0.26 & 0.12 & -0.02 \\
\hline $\begin{array}{l}\text { Percent } \\
\text { Latino/a }\end{array}$ & $-0.10^{* * *}$ & -1.14 & -0.20 & 0.17 & 0.17 & -0.04 & $-0.12 * * *$ & $-2.45^{*}$ & -0.01 & 0.31 & 0.17 & 0.10 \\
\hline $\begin{array}{l}\text { Med HH } \\
\text { Inc }\end{array}$ & $0.07 * * *$ & 0.47 & -0.03 & -0.12 & -0.12 & 0.01 & $0.08^{* * *}$ & 0.51 & -0.07 & 0.29 & -0.12 & -0.02 \\
\hline $\begin{array}{l}\text { Percent } \\
\text { College }\end{array}$ & 0.03 & $-1.72 *$ & -0.46 & -0.18 & -0.18 & -0.02 & $-0.10^{* * *}$ & $-1.46^{*}$ & -0.14 & $1.91^{* * *}$ & -0.35 & 0.08 \\
\hline $\begin{array}{l}\text { Percent } \\
\text { Child }\end{array}$ & 0.05 & -0.39 & 0.09 & -0.22 & -0.22 & -0.23 & $0.09 * *$ & 1.86 & -0.26 & -1.56 & -0.72 & 0.01 \\
\hline $\begin{array}{l}\text { Percent } \\
\text { Older }\end{array}$ & $0.15^{* * *}$ & 0.82 & 0.47 & 0.25 & 0.25 & -0.29 & 0.03 & 1.46 & -0.43 & 0.51 & -0.40 & -0.06 \\
\hline Pop Den & $0.08^{* * *}$ & $0.68^{* * *}$ & $0.17^{* * *}$ & $0.10^{*}$ & $0.10^{*}$ & $0.04^{*}$ & $0.10^{* * *}$ & $0.73^{* * *}$ & $0.14^{* * *}$ & 0.04 & $0.16^{* * *}$ & 0.00 \\
\hline $\begin{array}{c}\text { Adjusted } \\
R^{2} \\
\end{array}$ & 0.75 & 0.43 & 0.80 & 0.28 & 0.64 & 0.95 & 0.70 & 0.22 & 0.42 & 0.27 & 0.52 & 0.52 \\
\hline $\begin{array}{c}\text { Urban } \\
\text { Area }\end{array}$ & \multicolumn{6}{|c|}{ Salt Lake City } & \multicolumn{6}{|c|}{ Kansas City } \\
\hline Variables & XS & $\begin{array}{l}\text { S-L_ } \\
\text { walk }\end{array}$ & $\begin{array}{l}\text { S-L_ } \\
\text { bike }\end{array}$ & $\begin{array}{c}\mathrm{XL}_{-} \\
\text {walk }\end{array}$ & $\begin{array}{l}\mathrm{XL}_{-} \\
\text {bike }\end{array}$ & $\begin{array}{c}\mathrm{XL}_{-} \\
\text {drive }\end{array}$ & XS & $\begin{array}{l}\mathrm{S}-\mathrm{L}_{-} \\
\text {walk }\end{array}$ & $\begin{array}{l}\text { S-L_ } \\
\text { bike }\end{array}$ & $\begin{array}{c}\mathrm{XL}_{-} \\
\text {walk }\end{array}$ & $\begin{array}{l}\mathrm{XL}_{-} \\
\text {bike }\end{array}$ & $\begin{array}{c}\mathrm{XL}_{-} \\
\text {drive }\end{array}$ \\
\hline Intercept & $-0.86^{* * *}$ & -5.05 & 1.08 & 1.07 & 0.55 & $14.57^{* * *}$ & $-0.59 * * *$ & -3.68 & 2.04 & -2.11 & $4.43^{* *}$ & $10.35^{* * *}$ \\
\hline $\begin{array}{c}\text { Percent } \\
\text { NH Black }\end{array}$ & $-0.13^{*}$ & -0.50 & 0.07 & -2.57 & 1.30 & 0.00 & $-0.13^{* * *}$ & 0.35 & 0.27 & 0.97 & 0.22 & -0.01 \\
\hline $\begin{array}{c}\text { Percent } \\
\text { NH Asian }\end{array}$ & $-0.10^{* *}$ & -0.41 & -0.52 & 0.52 & -1.73 & 0.00 & $-0.24^{* * *}$ & -2.35 & 0.11 & 0.23 & -0.88 & 0.02 \\
\hline $\begin{array}{c}\text { Percent } \\
\text { Latino/a }\end{array}$ & $-0.06^{* *}$ & -1.17 & -0.04 & -0.65 & -0.48 & 0.00 & $-0.07^{* *}$ & 0.59 & 0.10 & 0.32 & -0.16 & -0.02 \\
\hline $\begin{array}{l}\text { Med HH } \\
\text { Inc }\end{array}$ & $0.04 * * *$ & 0.32 & 0.16 & 0.30 & 0.52 & 0.00 & $0.03^{* * *}$ & -0.13 & -0.08 & 0.26 & 0.05 & 0.00 \\
\hline $\begin{array}{l}\text { Percent } \\
\text { College } \\
\end{array}$ & -0.01 & -1.23 & -0.68 & -0.02 & -1.54 & 0.00 & $-0.05^{*}$ & -0.65 & $-0.73 *$ & 0.47 & -0.22 & -0.01 \\
\hline $\begin{array}{l}\text { Percent } \\
\text { Child }\end{array}$ & $0.07^{*}$ & 1.14 & 0.01 & -0.19 & 0.24 & 0.00 & $0.10^{* * *}$ & $-3.45^{*}$ & -0.76 & 0.11 & -0.07 & -0.04 \\
\hline $\begin{array}{l}\text { Percent } \\
\text { Older }\end{array}$ & $0.13^{* * *}$ & -0.23 & -0.11 & 0.07 & 2.28 & 0.00 & $0.10^{* * *}$ & -1.36 & 0.81 & 0.88 & 0.10 & 0.02 \\
\hline Pop Den & $0.06^{* * *}$ & 0.01 & $0.11 *$ & $-0.35^{*}$ & -0.04 & $0.00^{* *}$ & $0.06^{* * *}$ & $0.63^{* * *}$ & $0.36^{* * *}$ & 0.02 & 0.03 & $0.01 * *$ \\
\hline $\begin{array}{c}\text { Adjusted } \\
R^{2}\end{array}$ & 0.97 & 0.31 & 0.70 & 0.31 & 0.71 & 0.97 & 0.72 & 0.27 & 0.64 & 0.21 & 0.63 & 0.97 \\
\hline $\begin{array}{c}\text { Urban } \\
\text { Area }\end{array}$ & \multicolumn{6}{|c|}{ Fresno } & \multicolumn{6}{|c|}{ Grand Rapids } \\
\hline Variables & XS & $\begin{array}{l}\text { S-L_- } \\
\text { walk }\end{array}$ & $\begin{array}{l}\text { S-L_ } \\
\text { bike }\end{array}$ & $\begin{array}{c}\mathrm{XL}_{-} \\
\text {walk }\end{array}$ & $\begin{array}{l}\mathrm{XL} \\
\text { bike }\end{array}$ & $\begin{array}{c}\mathrm{XL}_{-} \\
\text {drive }\end{array}$ & XS & $\begin{array}{l}\text { S-L_ } \\
\text { walk }\end{array}$ & $\begin{array}{l}\text { S-L_ } \\
\text { bike }\end{array}$ & $\begin{array}{c}\mathrm{XL}_{-} \\
\text {walk }\end{array}$ & $\begin{array}{l}\mathrm{XL} \\
\text { bike }\end{array}$ & $\begin{array}{c}\mathrm{XL}_{-} \\
\text {drive }\end{array}$ \\
\hline Intercept & $-0.66^{* * *}$ & -13.93 & 1.45 & -1.93 & 4.65 & $8.29 * * *$ & $-0.64^{* * *}$ & -4.02 & 5.31 & -0.49 & 3.58 & $13.81^{* * *}$ \\
\hline $\begin{array}{c}\text { Percent } \\
\text { NH Black }\end{array}$ & -0.06 & 6.09 & 0.38 & 1.23 & -0.69 & 0.00 & -0.05 & -3.29 & -1.09 & 1.31 & 0.20 & 0.00 \\
\hline $\begin{array}{c}\text { Percent } \\
\text { NH Asian }\end{array}$ & $-0.10^{* * *}$ & -0.49 & 0.31 & 1.02 & -0.52 & 0.00 & -0.01 & -6.58 & -1.32 & -3.56 & -4.08 & 0.00 \\
\hline $\begin{array}{c}\text { Percent } \\
\text { Latino/a }\end{array}$ & $-0.05^{*}$ & -2.11 & 0.32 & 0.27 & -0.84 & -0.01 & $-0.11^{* *}$ & -0.74 & -1.48 & -1.07 & 0.91 & 0.00 \\
\hline $\begin{array}{l}\text { Med HH } \\
\text { Inc }\end{array}$ & $0.04^{* * *}$ & 1.02 & 0.12 & 0.09 & -0.24 & -0.01 & $0.03^{* *}$ & -0.39 & -0.38 & 0.20 & 0.18 & 0.00 \\
\hline $\begin{array}{l}\text { Percent } \\
\text { College }\end{array}$ & $0.07^{* *}$ & -3.54 & -0.22 & -0.38 & 0.43 & 0.02 & 0.01 & -0.71 & -1.03 & 1.17 & -0.61 & 0.00 \\
\hline $\begin{array}{c}\text { Percent } \\
\text { Child }\end{array}$ & 0.00 & 0.52 & -0.33 & 0.28 & -0.01 & 0.01 & 0.05 & 0.85 & 1.05 & -0.41 & 0.76 & 0.00 \\
\hline $\begin{array}{l}\text { Percent } \\
\text { Older }\end{array}$ & $0.08^{*}$ & -2.97 & 0.26 & 0.01 & -0.49 & 0.00 & 0.08 * & -2.74 & 1.73 & 0.20 & 0.61 & 0.00 \\
\hline Pop Den & $0.04^{* * *}$ & 0.48 & $0.14^{* *}$ & 0.13 & 0.11 & 0.00 & $0.05^{* * *}$ & $0.90 * *$ & 0.25 & -0.11 & -0.05 & 0.00 \\
\hline $\begin{array}{c}\text { Adjusted } \\
R^{2}\end{array}$ & 0.68 & 0.10 & 0.75 & 0.39 & 0.68 & 0.50 & 0.70 & 0.42 & 0.59 & 0.13 & 0.59 & 0.91 \\
\hline
\end{tabular}

${ }^{*} p \leq 0.05 ;{ }^{* *} p \leq 0.01 ;{ }^{* * *} p \leq 0.001$; shaded cells show statistically significant results for environmental injustice (orange) and justice (green) $(p \leq 0.05)$. 
Table A2. Spatial filtering model results by urban area (cities in South and Northeast regions).

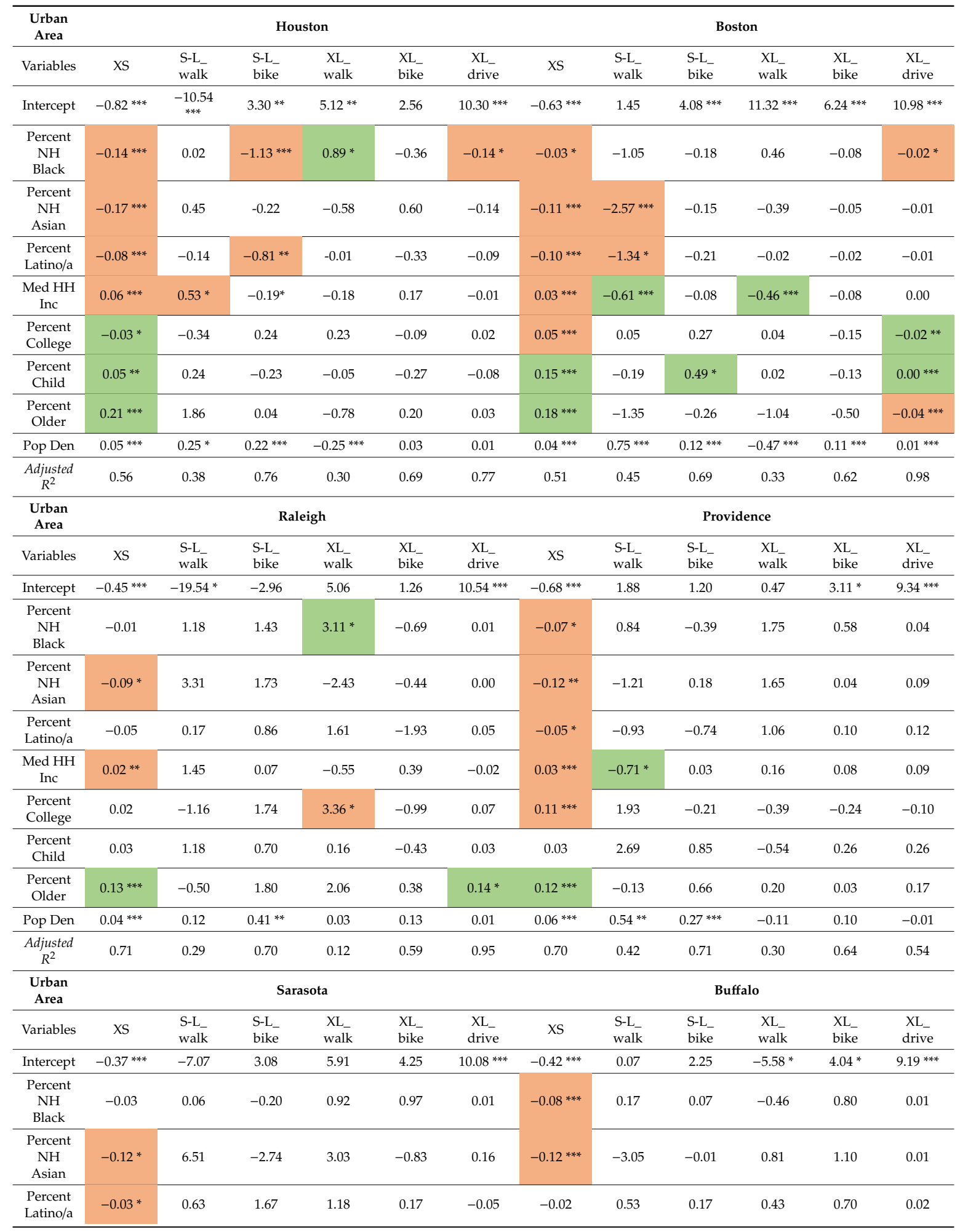


Table A2. Cont.

\begin{tabular}{|c|c|c|c|c|c|c|c|c|c|c|c|c|}
\hline \multirow{2}{*}{$\begin{array}{c}\text { Urban } \\
\text { Area } \\
\text { Med HH } \\
\text { Inc }\end{array}$} & \multicolumn{6}{|c|}{ Houston } & \multicolumn{6}{|c|}{ Boston } \\
\hline & 0.02 ** & -0.03 & -0.22 & -0.17 & -0.08 & -0.06 & 0.01 * & -0.51 & -0.06 & 0.46 & 0.02 & 0.00 \\
\hline $\begin{array}{l}\text { Percent } \\
\text { College }\end{array}$ & 0.03 & 0.94 & 1.08 & -1.60 & -1.35 & 0.13 & $0.05^{* *}$ & 0.30 & -0.29 & 0.71 & 0.06 & 0.00 \\
\hline $\begin{array}{l}\text { Percent } \\
\text { Child }\end{array}$ & -0.05 & 5.07 & 1.35 & -1.59 & -2.96 & 0.18 & 0.00 & 0.39 & -0.61 & -0.11 & -0.32 & -0.02 \\
\hline $\begin{array}{l}\text { Percent } \\
\text { Older }\end{array}$ & $-0.05^{* * *}$ & 0.33 & 0.73 & -0.22 & -1.02 & -0.03 & $0.08^{* * *}$ & -0.86 & 0.92 & $2.30 *$ & 0.82 & 0.01 \\
\hline Pop Den & $0.03^{* * *}$ & 0.33 & 0.06 & -0.34 & 0.21 & 0.01 & $0.05^{* * *}$ & $0.48^{* *}$ & $0.20^{* * *}$ & 0.14 & 0.01 & 0.00 \\
\hline $\begin{array}{c}\text { Adjusted } \\
R^{2}\end{array}$ & 0.55 & 0.38 & 0.62 & 0.21 & 0.66 & 0.97 & 0.62 & 0.43 & 0.80 & 0.20 & 0.66 & 0.97 \\
\hline
\end{tabular}

\section{References}

1. Chiesura, A. The role of urban parks for the sustainable city. Landsc. Urban Plan. 2004, 68, 129-138. [CrossRef]

2. Wolch, J.R.; Byrne, J.; Newell, J.P. Urban green space, public health, and environmental justice: The challenge of making cities "just green enough". Landsc. Urban Plan. 2014, 125, 234-244. [CrossRef]

3. Klemm, W.; Heusinkveld, B.G.; Lenzholzer, S.; van Hove, B. Street greenery and its physical and psychological impact on thermal comfort. Landsc. Urban Plan. 2015, 138, 87-98. [CrossRef]

4. Lu, Y.; Sarkar, C.; Xiao, Y. The effect of street-level greenery on walking behavior: Evidence from Hong Kong. Soc. Sci. Med. 2018, 208, 41-49. [CrossRef] [PubMed]

5. Silvera Seamans, G. Mainstreaming the environmental benefits of street trees. Urban For. Urban Green. 2013, 12, 2-11. [CrossRef]

6. Zhang, Y.; Dong, R. Impacts of street-visible greenery on housing prices: Evidence from a hedonic price model and a massive street view image dataset in Beijing. ISPRS Int. J. Geo-Inf. 2018, 7, 104. [CrossRef]

7. Konijnendijk, C.C.; Annerstedt, M.; Nielsen, A.B.; Maruthaveeran, S. Benefits of Urban Parks-A Systematic Review; International Federation of Parks and Recreation Administration: Copenhagen, Denmark, 2013.

8. Lee, A.C.K.; Maheswaran, R. The health benefits of urban green spaces: A review of the evidence. J. Public Health (Bangkok) 2011, 33, 212-222. [CrossRef] [PubMed]

9. Yang, J.; McBride, J.; Zhou, J.; Sun, Z. The urban forest in Beijing and its role in air pollution reduction. Urban For. Urban Green. 2005, 3, 65-78. [CrossRef]

10. Kaplan, R. The Nature of the View from Home. Environ. Behav. 2001, 33, 507-542. [CrossRef]

11. Lutzenhiser, M.; Netusil, N.R. The effect of open spaces on a home's sale price. Contemp. Econ. Policy 2001, 19, 291-298. [CrossRef]

12. Brown, G.; Schebella, M.F.; Weber, D. Using participatory GIS to measure physical activity and urban park benefits. Landsc. Urban Plan. 2014, 121, 34-44. [CrossRef]

13. Fernández-Juricic, E. Bird community composition patterns in urban parks of Madrid: The role of age, size and isolation. Ecol. Res. 2000, 15, 373-383. [CrossRef]

14. Jansen, F.M.; Ettema, D.F.; Kamphuis, C.B.M.; Pierik, F.H.; Dijst, M.J. How do type and size of natural environments relate to physical activity behavior? Health Place 2017, 46, 73-81. [CrossRef] [PubMed]

15. Oliver, A.J.; Hong-Wa, C.; Devonshire, J.; Olea, K.R.; Rivas, G.F.; Gahl, M.K. Avifauna richness enhanced in large, isolated urban parks. Landsc. Urban Plan. 2011, 102, 215-225. [CrossRef]

16. Rundle, A.; Quinn, J.; Lovasi, G.; Bader, M.D.M.; Yousefzadeh, P.; Weiss, C.; Neckerman, K. Associations between body mass index and park proximity, size, cleanliness, and recreational facilities. Am. J. Health Promot. 2013, 27, 262-269. [CrossRef] [PubMed]

17. Sugiyama, T.; Francis, J.; Middleton, N.J.; Owen, N.; Giles-CortI, B. Associations between recreational walking and attractiveness, size, and proximity of neighborhood open spaces. Am. J. Public Health 2010, 100, 1752-1757. [CrossRef]

18. Wood, L.; Hooper, P.; Foster, S.; Bull, F. Public green spaces and positive mental health-Investigating the relationship between access, quantity and types of parks and mental wellbeing. Health Place 2017, 48, 63-71. [CrossRef]

19. Gupta, K.; Roy, A.; Luthra, K.; Maithani, S. Mahavir GIS based analysis for assessing the accessibility at hierarchical levels of urban green spaces. Urban For. Urban Green. 2016, 18, 198-211. [CrossRef] 
20. Bell, S.; Hamilton, V.; Montarzino, A.; Rothnie, H.; Travlou, P.; Alves, S. Greenspace and Quality of Life: A Critical Literature Review; Greenspace Scotland: Stirling, Scotland, 2008.

21. Rigolon, A. A complex landscape of inequity in access to urban parks: A literature review. Landsc. Urban Plan. 2016, 153, 160-169. [CrossRef]

22. Rigolon, A.; Browning, M.; Lee, K.; Shin, S. Access to urban green space in cities of the global south: A systematic literature review. Urban Sci. 2018, 2, 67. [CrossRef]

23. Schüle, S.A.; Hilz, L.K.; Dreger, S.; Bolte, G. Social inequalities in environmental resources of green and blue spaces: A review of evidence in the WHO European region. Int. J. Environ. Res. Public Health 2019, 16, 1216. [CrossRef] [PubMed]

24. Flocks, J.; Escobedo, F.; Wade, J.; Varela, S.; Wald, C. Environmental justice implications of urban tree cover in Miami-Dade County, Florida. Environ. Justice 2011, 4, 125-134. [CrossRef]

25. Nesbitt, L.; Meitner, M.J.; Girling, C.; Sheppard, S.R.J.; Lu, Y. Who has access to urban vegetation? A spatial analysis of distributional green equity in 10 US cities. Landsc. Urban Plan. 2019, 181, 51-79. [CrossRef]

26. Schwarz, K.; Fragkias, M.; Boone, C.G.; Zhou, W.; McHale, M.; Grove, J.M.; O'Neil-Dunne, J.; McFadden, J.P.; Buckley, G.L.; Childers, D.; et al. Trees grow on money: Urban tree canopy cover and environmental justice. PLoS ONE 2015, 10, e0122051. [CrossRef] [PubMed]

27. Zhou, X.; Kim, J. Social disparities in tree canopy and park accessibility: A case study of six cities in Illinois using GIS and remote sensing. Urban For. Urban Green. 2013, 12, 88-97. [CrossRef]

28. Landry, S.M.; Chakraborty, J. Street trees and equity: Evaluating the spatial distribution of an urban amenity. Environ. Plan. A 2009, 41, 2651-2670. [CrossRef]

29. Pham, T.T.H.; Apparicio, P.; Landry, S.; Lewnard, J. Disentangling the effects of urban form and socio-demographic context on street tree cover: A multi-level analysis from Montréal. Landsc. Urban Plan. 2017, 157, 422-433. [CrossRef]

30. Li, X.; Zhang, C.; Li, W.; Kuzovkina, Y.A.; Weiner, D. Who lives in greener neighborhoods? The distribution of street greenery and its association with residents' socioeconomic conditions in Hartford, Connecticut, USA. Urban For. Urban Green. 2015, 14, 751-759. [CrossRef]

31. Boone, C.G.; Buckley, G.L.; Grove, J.M.; Sister, C. Parks and people: An environmental justice inquiry in Baltimore, Maryland. Ann. Assoc. Am. Geogr. 2009, 99, 767-787. [CrossRef]

32. Rigolon, A. Parks and young people: An environmental justice study of park proximity, acreage, and quality in Denver, Colorado. Landsc. Urban Plan. 2017, 165, 73-83. [CrossRef]

33. Rigolon, A.; Németh, J. What Shapes Uneven Access to Urban Amenities? Thick Injustice and the Legacy of Racial Discrimination in Denver's Parks. J. Plan. Educ. Res. 2018. [CrossRef]

34. Sister, C.; Wolch, J.; Wilson, J. Got green? addressing environmental justice in park provision. GeoJournal 2010, 75, 229-248. [CrossRef]

35. Agyeman, J. Introducing Just Sustainabilities: Policy, Planning, and Practice; Zed Books: London, UK, 2013; ISBN 9781780324098.

36. Wolch, J.; Wilson, J.P.; Fehrenbach, J. Parks and park funding in los angeles: An equity-mapping analysis. Urban Geogr. 2005, 26, 4-35. [CrossRef]

37. Davies, I.P.; Christensen, J.; Kareiva, P. Assessing the flow to low-income urban areas of conservation and environmental funds approved by California's Proposition 84. PLoS ONE 2019, 14, e0211925. [CrossRef]

38. Meerow, S.; Pajouhesh, P.; Miller, T.R. Social equity in urban resilience planning. Local Environ. 2019, 24, 793-808. [CrossRef]

39. Hero, J.O.; Zaslavsky, A.M.; Blendon, R.J. The United States leads other nations in differences by income in perceptions of health and health care. Health Aff. 2017, 36, 1032-1040. [CrossRef]

40. National Center for Health Statistics (US). Health, United States, 2015: With Special Feature on Racial and Ethnic Health Disparities; Centers for Disease Control and Prevention: Atlanta, GA, USA, 2016.

41. OCDE Health for Everyone?: Social inequalities in health and health systems. OECD Health Policy Stud. 2019. [CrossRef]

42. European Commission. Commission Staff Working Document Report on Health Inequalities in the European Union; European Commission: Brussels, Belgium, 2013; Volume 45.

43. Markevych, I.; Schoierer, J.; Hartig, T.; Chudnovsky, A.; Hystad, P.; Dzhambov, A.M.; de Vries, S.; Triguero-Mas, M.; Brauer, M.; Nieuwenhuijsen, M.J.; et al. Exploring pathways linking greenspace to health: Theoretical and methodological guidance. Environ. Res. 2017, 158, 301-317. [CrossRef] 
44. Nieuwenhuijsen, M.J.; Khreis, H.; Triguero-Mas, M.; Gascon, M.; Dadvand, P. Fifty shades of green. Epidemiology 2017, 28, 63-71. [CrossRef]

45. Loukaitou-Sideris, A.; Stieglitz, O. Children in Los Angeles parks: A study of equity, quality and children's satisfaction with neighbourhood parks. Town Plan. Rev. 2002, 73, 467-488. [CrossRef]

46. Romero, A.J. Low-income neighborhood barriers and resources for adolescents' physical activity. J. Adolesc. Health 2005, 36, 253-259. [CrossRef] [PubMed]

47. Wright Wendel, H.E.; Zarger, R.K.; Mihelcic, J.R. Accessibility and usability: Green space preferences, perceptions, and barriers in a rapidly urbanizing city in Latin America. Landsc. Urban Plan. 2012, 107, 272-282. [CrossRef]

48. Carrington, K.; Hogg, R.; Scott, J.; Sozzo, M.; Walters, R. Southern Criminology; Routledge: Abingdon, UK, 2018; ISBN 9781351761499.

49. Taylor, D.E. The rise of the environmental justice paradigm: Injustice framing and the social construction of environmental discourses. Am. Behav. Sci. 2000, 43, 508-580. [CrossRef]

50. Schell, C.J.; Dyson, K.; Fuentes, T.L.; Des Roches, S.; Harris, N.C.; Miller, D.S.; Woelfle-Erskine, C.A.; Lambert, M.R. The ecological and evolutionary consequences of systemic racism in urban environments. Science (80-.) 2020, eaay4497. [CrossRef]

51. Carrington, K.; Hogg, R.; Sozzo, M. Southern Criminology. Br. J. Criminol. 2016, 56, 1-20. [CrossRef]

52. Rigolon, A.; Browning, M.; Jennings, V. Inequities in the quality of urban park systems: An environmental justice investigation of cities in the United States. Landsc. Urban Plan. 2018, 178, 156-169. [CrossRef]

53. Agyeman, J.; Evans, T. Toward just sustainability in urban communities: Building equity rights with sustainable solutions. Ann. Am. Acad. Pol. Soc. Sci. 2003, 590, 35-53. [CrossRef]

54. Anguelovski, I. New directions in urban environmental justice: Rebuilding community, addressing trauma, and remaking place. J. Plan. Educ. Res. 2013, 33, 160-175. [CrossRef]

55. Rigolon, A. Nonprofits and park equity in Los Angeles: A promising way forward for environmental justice. Urban Geogr. 2019, 40, 984-1009. [CrossRef]

56. Campbell, S. Green Cities, Growing Cities, Just Cities?: Urban planning and the contradictions of sustainable development. J. Am. Plan. Assoc. 1996, 62, 296-312. [CrossRef]

57. Schlosberg, D. Reconceiving environmental justice: Global movements and political theories. Env. Polit. 2004, 13, 517-540. [CrossRef]

58. Boone, C.G.; Fragkias, M. Connecting environmental justice, sustainability, and vulnerability. In Urbanization and Sustainability: Linking Urban Ecology, Environmental Justice and Global Environmental Change; Springer: Dordrecth, The Netherlands, 2013; pp. 49-59. ISBN 9789400756663.

59. Levy, B.S.; Patz, J.A. Climate change, human rights, and social justice. Ann. Glob. Health 2015, 81, 310-322. [CrossRef] [PubMed]

60. Blanck, H.M.; Allen, D.; Bashir, Z.; Gordon, N.; Goodman, A.; Merriam, D.; Rutt, C. Let's go to the park today: The role of parks in obesity prevention and improving the public's health. Child. Obes. 2012, 8, 423-428. [CrossRef] [PubMed]

61. Heynen, N.; Perkins, H.A.; Roy, P. The political ecology of uneven urban green space: The impact of political economy on race and ethnicity in producing environmental inequality in Milwaukee. Urban Aff. Rev. 2006, 42, 3-25. [CrossRef]

62. U.S. Census bureau urban area criteria for the 2010 census. Fed. Regist. 2011, 76, 53030-53043.

63. Organisation for Economic Co-operation and Development (OECD). Urban Population by City Size. Available online: https://data.oecd.org/popregion/urban-population-by-city-size.htm (accessed on 11 July 2020).

64. Szymańska, D.; Lewandowska, A.; Rogatka, K. Temporal trend of green areas in Poland between 2004 and 2012. Urban For. Urban Green. 2015, 14, 1009-1016. [CrossRef]

65. Lovasi, G.S.; Jacobson, J.S.; Quinn, J.W.; Neckerman, K.M.; Ashby-Thompson, M.N.; Rundle, A. Is the environment near home and school associated with physical activity and adiposity of urban preschool children? J. Urban Health 2011, 88, 1143-1157. [CrossRef] [PubMed]

66. Taylor, M.S.; Wheeler, B.W.; White, M.P.; Economou, T.; Osborne, N.J. Research note: Urban street tree density and antidepressant prescription rates-A cross-sectional study in London, UK. Landsc. Urban Plan. 2015, 136, 174-179. [CrossRef] 
67. Davis, A.Y.; Jung, J.; Pijanowski, B.C.; Minor, E.S. Combined vegetation volume and "greenness" affect urban air temperature. Appl. Geogr. 2016, 71, 106-114. [CrossRef]

68. Nesbitt, L.; Meitner, M.J. Exploring relationships between socioeconomic background and Urban greenery in Portland, OR. Forests 2016, 7, 162. [CrossRef]

69. Mcbride, J. Mapping Chicago Area Urban Tree Canopy Using Color Infrared Imagery; Lund University: Lund, Sweden, 2011.

70. U.S. Census Bureau. TIGER/Line ${ }^{\circledR}$ Shapefiles 2019 Economic and Statistics Administration; 2019. Available online: https://www.census.gov/geographies/mapping-files/time-series/geo/tiger-line-file.html (accessed on 11 July 2020).

71. American Association of State Highway and Transportation Officials. A Policy on Geometric Design of Highways and Streets; American Association of State Highway and Transportation Officials: Washington, DC, USA, 2018.

72. Mertes, J.D.; Hall, J.R. Park, Recreation, Open Space and Greenway Guidelines; National Recreation and Park Association: Arlington, VA, USA, 1995.

73. Czerniak, J.; Hargreaves, G.; Beardsley, J. Large Parks; Princeton Architectural Press: New York, NY, USA, 2007.

74. Cohen, D.A.; Han, B.; Nagel, C.J.; Harnik, P.; McKenzie, T.L.; Evenson, K.R.; Marsh, T.; Williamson, S.; Vaughan, C.; Katta, S. The first national study of neighborhood parks: Implications for physical activity. Am. J. Prev. Med. 2016, 51, 419-426. [CrossRef] [PubMed]

75. The Trust for Public Land ParkServe ${ }^{\circledR}$ Data. Available online: https://www.tpl.org/parkserve/downloads (accessed on 11 July 2020).

76. Sarkar, C.; Webster, C.; Pryor, M.; Tang, D.; Melbourne, S.; Zhang, X.; Jianzheng, L. Exploring associations between urban green, street design and walking: Results from the Greater London boroughs. Landsc. Urban Plan. 2015, 143, 112-125. [CrossRef]

77. Derose, K.P.; Han, B.; Williamson, S.; Cohen, D.A. Racial-ethnic variation in park use and physical activity in the city of Los Angeles. J. Urban Health 2015, 92, 1011-1023. [CrossRef] [PubMed]

78. Washington, T.S. Neighborhood Parks and Physical Activity Levels; Arizona State University: Tempe, AZ, USA, 2011.

79. Willemse, L. Some perceptions and preferences of residents' use of community neighbourhood parks in Mitchells Plain, Cape Town. Stads Streeksbeplanning Town Reg. Plan. 2015, 2015, 15-30.

80. Downward, P.; Lumsdon, L. Tourism transport and visitor spending: A study in the North York Moors, National Park, UK. J. Travel Res. 2004, 42, 415-420. [CrossRef]

81. Pettebone, D.; Newman, P.; Lawson, S.R.; Hunt, L.; Monz, C.; Zwiefka, J. Estimating visitors' travel mode choices along the Bear Lake Road in Rocky Mountain National Park. J. Transp. Geogr. 2011, 19, 1210-1221. [CrossRef]

82. Talen, E. Neighborhoods as service providers: A methodology for evaluating pedestrian access. Environ. Plan. B Plan. Des. 2003, 30, 181-200. [CrossRef]

83. Environmental Protection Agency. Office of Environmental Justice Office of Environmental Justice in Action. Available online: www.epa.gov/environmentaljustice (accessed on 11 July 2020).

84. European Environment Agency Environmental justice, environmental hazards and the vulnerable in European society. Available online: https:/www.eea.europa.eu/publications/unequal-exposure-and-unequal-impacts/ environmental-justice-environmental-hazards-and/view (accessed on 11 July 2020).

85. Beretta, I. Some Highlights on the Concept of Environmental Justice and its Use. E-Cadernos CES 2012, 17. [CrossRef]

86. Day, R. Environmental justice and older age: Consideration of a qualitative neighbourhood-based study. Environ. Plan. A 2010, 42, 2658-2673. [CrossRef]

87. Maantay, J.; Maroko, A. Mapping urban risk: Flood hazards, race, \& environmental justice in New York. Appl. Geogr. 2009, 29, 111-124. [CrossRef]

88. Rivera, R.; Rosenbaum, J. Racial disparities in police stops in US cities. Significance 2020, 17, 4-5. [CrossRef]

89. Grineski, S.E.; Collins, T.W.; Morales, D.X. Asian Americans and disproportionate exposure to carcinogenic hazardous air pollutants: A national study. Soc. Sci. Med. 2017, 185, 71-80. [CrossRef] [PubMed]

90. Grineski, S.; Morales, D.X.; Collins, T.; Hernandez, E.; Fuentes, A. The burden of carcinogenic air toxics among Asian Americans in four US metro areas. Popul. Environ. 2019, 40, 257-282. [CrossRef] [PubMed]

91. Liévanos, R.S. Race, deprivation, and immigrant isolation: The spatial demography of air-toxic clusters in the continental United States. Soc. Sci. Res. 2015, 54, 50-67. [CrossRef] [PubMed] 
92. Carter-Pokras, O.; Zambrana, R.E.; Poppell, C.F.; Logie, L.A.; Guerrero-Preston, R. The environmental health of latino children. J. Pediatr. Health Care 2007, 21, 307-314. [CrossRef] [PubMed]

93. Cutts, B.B.; Darby, K.J.; Boone, C.G.; Brewis, A. City structure, obesity, and environmental justice: An integrated analysis of physical and social barriers to walkable streets and park access. Soc. Sci. Med. 2009, 69, 1314-1322. [CrossRef] [PubMed]

94. Wang, Y. Cross-national comparison of childhood obesity: The epidemic and the relationship between obesity and socioeconomic status. Int. J. Epidemiol. 2001, 30, 1129-1136. [CrossRef]

95. Bryan, S.; Walsh, P. Physical activity and obesity in canadian women. BMC Womens. Health 2004, 4, S6. [CrossRef] [PubMed]

96. Hornberg, C.; Pauli, A. Child poverty and environmental justice. Int. J. Hyg. Environ. Health 2007, 210, 571-580. [CrossRef] [PubMed]

97. Shim, J.E.; Kim, S.J.; Kim, K.; Hwang, J.Y. Spatial disparity in food environment and household economic resources related to food insecurity in rural Korean households with older adults. Nutrients 2018, 10, 1514. [CrossRef]

98. Loukaitou-Sideris, A.; Sideris, A. What brings children to the park? Analysis and measurement of the variables affecting children's use of parks. J. Am. Plan. Assoc. 2010, 76, 89-107. [CrossRef]

99. Chen, W.Y.; Hu, F.Z.Y.; Li, X.; Hua, J. Strategic interaction in municipal governments' provision of public green spaces: A dynamic spatial panel data analysis in transitional China. Cities 2017, 71, 1-10. [CrossRef]

100. Griffith, D.A. Spatial Autocorrelation and Spatial Filtering: Gaining Understanding Through Theory and Scientific Visualization; Springer: Berlin/Heidelberg, Germany, 2003; ISBN 3540009329.

101. Thayn, J.B.; Simanis, J.M. Accounting for spatial autocorrelation in linear regression models using spatial filtering with eigenvectors. Ann. Assoc. Am. Geogr. 2013, 103, 47-66. [CrossRef]

102. Dormann, C.F. Effects of incorporating spatial autocorrelation into the analysis of species distribution data. Glob. Ecol. Biogeogr. 2007, 16, 129-138. [CrossRef]

103. Park, Y.M.; Kim, Y. A spatially filtered multilevel model to account for spatial dependency: Application to self-rated health status in South Korea. Int. J. Health Geogr. 2014, 13, 1-10. [CrossRef] [PubMed]

104. Perkins, H.A. Gramsci in green: Neoliberal hegemony through urban forestry and the potential for a political ecology of praxis. Geoforum 2011, 42, 558-566. [CrossRef]

105. Wilson, B. Urban Heat Management and the Legacy of Redlining. J. Am. Plan. Assoc. 2020, 1-15. [CrossRef]

106. Andersson, E.; McPhearson, T.; Kremer, P.; Gomez-Baggethun, E.; Haase, D.; Tuvendal, M.; Wurster, D. Scale and context dependence of ecosystem service providing units. Ecosyst. Serv. 2015, 12, 157-164. [CrossRef]

107. Bowler, D.E.; Buyung-Ali, L.; Knight, T.M.; Pullin, A.S. Urban greening to cool towns and cities: A systematic review of the empirical evidence. Landsc. Urban Plan. 2010, 97, 147-155. [CrossRef]

108. Czembrowski, P.; Kronenberg, J. Hedonic pricing and different urban green space types and sizes: Insights into the discussion on valuing ecosystem services. Landsc. Urban Plan. 2016, 146, 11-19. [CrossRef]

109. Bäckstrand, K.; Lövbrand, E. Planting trees to mitigate climate change: Contested discourses of ecological modernization, green governmentality and civic environmentalism. Glob. Environ. Polit. 2006, 6, 50-75. [CrossRef]

110. Bastin, J.F.; Finegold, Y.; Garcia, C.; Mollicone, D.; Rezende, M.; Routh, D.; Zohner, C.M.; Crowther, T.W. The global tree restoration potential. Science (80-.) 2019, 364, 76-79. [CrossRef] [PubMed]

111. Bacci, L.; Morabito, M.; Raschi, A.; Ugolini, F. Thermohygrometric conditions of some urban parks of florence (Italy) and their effects on human well-being. Trees 2003, 6 .

112. Chang, C.R.; Li, M.H.; Chang, S.D. A preliminary study on the local cool-island intensity of Taipei city parks. Landsc. Urban Plan. 2007, 80, 386-395. [CrossRef]

113. De Vries, S.; van Dillen, S.M.E.; Groenewegen, P.P.; Spreeuwenberg, P. Streetscape greenery and health: Stress, social cohesion and physical activity as mediators. Soc. Sci. Med. 2013, 94, 26-33. [CrossRef] [PubMed]

114. Byrne, J.; Ambrey, C.; Portanger, C.; Lo, A.; Matthews, T.; Baker, D.; Davison, A. Could urban greening mitigate suburban thermal inequity?: The role of residents' dispositions and household practices. Environ. Res. Lett. 2016, 11. [CrossRef]

115. Hughey, S.M.; Walsemann, K.M.; Child, S.; Powers, A.; Reed, J.A.; Kaczynski, A.T. Using an environmental justice approach to examine the relationships between park availability and quality indicators, neighborhood disadvantage, and racial/ethnic composition. Landsc. Urban Plan. 2016, 148, 159-169. [CrossRef] 
116. Duvarci, Y.; Yigitcanlar, T. Integrated modeling approach for the transportation disadvantaged. J. Urban Plan. Dev. 2007, 133, 188-200. [CrossRef]

117. Goddard, T. Theorizing bicycle justice using social psychology: Examining the intersection of mode and race with the conceptual model of roadway interactions. In Bicycle Justice and Urban Transformation; Golub, A., Hoffmann, M.L., Lugo, A.E., Sandoval, G.F., Eds.; Routledge: Abingdon, UK, 2016; pp. 100-114, ISBN 9781138950245.

118. Xiao, Y.; Wang, Z.; Li, Z.; Tang, Z. An assessment of urban park access in Shanghai-Implications for the social equity in urban China. Landsc. Urban Plan. 2017, 157, 383-393. [CrossRef]

119. Freeman, S.; Eykelbosh, A. COVID-19 and Outdoor Safety: Considerations for Use of Outdoor Recreational Spaces; National Collaborating Centre for Environmental Health: Vancouver, BC, Canada, 2020.

120. Chang, Z.; Chen, J.; Li, W.; Li, X. Public transportation and the spatial inequality of urban park accessibility: New evidence from Hong Kong. Transp. Res. Part D Transp. Environ. 2019, 76, 111-122. [CrossRef]

121. Zhang, X.; Lu, H.; Holt, J.B. Modeling spatial accessibility to parks: A national study. Int. J. Health Geogr. 2011, 10, 1-14. [CrossRef]

122. Garrison, J.D. Environmental justice in theory and practice: Measuring the equity outcomes of Los Angeles and New York's "Million Trees" campaigns. J. Plan. Educ. Res. 2018. [CrossRef]

123. Garrison, J.D. Seeing the park for the trees: New York's "Million Trees" campaign vs. the deep roots of environmental inequality. Environ. Plan. B Urban Anal. City Sci. 2019, 46, 914-930. [CrossRef]

124. TreePeople First Look: 300 Free Fruit Trees Planted for San Fernando. Available online: https://blog. treepeople.org/treepeople-news/2018/02/san-fernando-fruit-trees (accessed on 11 July 2020).

125. California Department of Forestry and Fire Protection Urban and Community Forestry Grant Guidelines 2017/2018. Available online: https://www.fire.ca.gov/grants/urban-and-community-forestry-grant-programs/ (accessed on 11 July 2020).

126. Los Angeles County Metropolitan Transportation Authority. Next Stop: More Access to Open Spaces. Transit TO Parks Strategic Plan; Los Angeles County Metropolitan Transportation Authority: Los Angeles, CA, USA, 2019.

127. Chen, Y.; Wong, N.H. Thermal benefits of city parks. Energy Build. 2006, 38, 105-120. [CrossRef]

128. Long, J. Constructing the narrative of the sustainability fix: Sustainability, social justice and representation in Austin, TX. Urban Stud. 2016, 53, 149-172. [CrossRef]

129. Goossens, C.; Oosterlynck, S.; Bradt, L. Livable streets? Green gentrification and the displacement of longtime residents in Ghent, Belgium. Urban Geogr. 2019. [CrossRef]

130. Kwon, Y.; Joo, S.; Han, S.; Park, C. Mapping the distribution pattern of gentrification near urban parks in the case of Gyeongui Line Forest Park, Seoul, Korea. Sustainability 2017, 9, 231. [CrossRef]

131. Rigolon, A.; Németh, J. Green gentrification or 'just green enough': Do park location, size and function affect whether a place gentrifies or not? Urban Stud. 2020, 57, 402-420. [CrossRef] 